\title{
Quantitative secretome and glycome of primary human adipocytes during insulin resistance
}

\author{
Jae-Min Lim ${ }^{1,2,5}$, Edith E Wollaston-Hayden ${ }^{1,3}$, Chin Fen Teo ${ }^{1,3}$, Dorothy Hausman ${ }^{4}$ and Lance Wells $s^{1,2,3^{*}}$
}

\begin{abstract}
Adipose tissue is both an energy storage depot and an endocrine organ. The impaired regulation of the secreted proteins of adipose tissue, known as adipocytokines, observed during obesity contributes to the onset of whole-body insulin resistance and the pathobiology of type 2 diabetes mellitus (T2DM). In addition, the global elevation of the intracellular glycosylation of proteins by O-linked $\beta$-N-acetylglucosamine (O-GlcNAc) via either genetic or pharmacological methods is sufficient to induce insulin resistance in both cultured cells and animal models. The elevation of global O-GlcNAc levels is associated with the altered expression of many adipocytokines. We have previously characterized the rodent adipocyte secretome during insulin sensitive and insulin resistant conditions. Here, we characterize and quantify the secretome and glycome of primary human adipocytes during insulin responsive and insulin resistant conditions generated by the classical method of hyperglycemia and hyperinsulinemia or by the pharmacological manipulation of O-GlcNAc levels. Using a proteomic approach, we identify 190 secreted proteins and report a total of 20 up-regulated and 6 down-regulated proteins that are detected in both insulin resistant conditions. Moreover, we apply glycomic techniques to examine (1) the sites of N-glycosylation on secreted proteins, (2) the structures of complex N-and O-glycans, and (3) the relative abundance of complex $\mathrm{N}$ - and O-glycans structures in insulin responsive and insulin resistant conditions. We identify 91 N-glycosylation sites derived from 51 secreted proteins, as well as 155 and 29 released N- and O-glycans respectively. We go on to quantify many of the $\mathrm{N}$ - and O-glycan structures between insulin responsive and insulin resistance conditions demonstrating no significant changes in complex glycosylation in the time frame for the induction of insulin resistance. Thus, our data support that the O-GlcNAc modification is involved in the regulation of adipocytokine secretion upon the induction of insulin resistance in human adipocytes.
\end{abstract}

Keywords: O-GlcNAc, Insulin resistance, Type 2 diabetes, Adipocytokine, Tandem mass spectrometry, Shotgun proteomics, Glycomics, N-linked, O-linked

\section{Introduction}

Type 2 diabetes mellitus (T2DM) is a rapidly growing problem in the industrialized world. In the United States, it is estimated that $8.3 \%$ of the population has diabetes [1]. T2DM results from a combination of insulin resistance and pancreatic beta-cell dysfunction [2]. The development of T2DM depends on both genetic and environmental risk factors [3]. The major environmental risk factor for the development of insulin resistance and T2DM is obesity. Increased white adipose tissue (WAT) mass during obesity causes a variety of problems related to the development

\footnotetext{
*Correspondence: Iwells@ccrc.uga.edu

${ }^{1}$ Complex Carbohydrate Research Center, The University of Georgia, 315 Riverbend Road, 30602-4712 Athens, Georgia

2Department of Chemistry, The University of Georgia, 30602 Athens, Georgia Full list of author information is available at the end of the article
}

of insulin resistance. It is now established that WAT acts as a lipid metabolism modulator as well as an endocrine organ [4].

The secreted proteins of adipose tissue, known as adipocytokines, can act in a paracrine or endocrine manner to modulate a variety of processes such as inflammation and whole-body energy homeostasis. During obesity, adipocytokine secretion is altered, which can lead to the development of whole-body insulin resistance and T2DM $[5,6]$. Although many adipocytokines have been identified using methods such as mass spectrometry-based proteomics, the alteration in the adipose tissue secretome for normal vs. insulin resistant human adipose tissue has not been well-defined [7]. Several adipocytokines identified in rodents have different expression patterns in humans highlighting the need for quantitative proteomic studies 
in human adipose tissue $[8,9]$. To achieve a more physiological representation of the adipose tissue secretome, we use primary human pre-adipocytes derived from human adipose tissue rather than an adipocyte cell line [10].

The regulation of adipocytokine expression during insulin resistance is still unclear in many cases. One possible way for cells to sense nutrient abundance and modulate insulin sensitivity and adipocytokine expression is through the hexosamine biosynthetic pathway (HBP). Excessive flux through the HBP results in insulin resistance, thereby limiting the amount of glucose that enters the cell and the resulting toxicity $[11,12]$. Flux through the HBP also modulates the expression of several adipocytokines [13-16]. The final product of the HBP is UDP-GlcNAc, which is the sugar donor for the enzyme O-GlcNAc transferase (OGT) that adds the O-linked $\beta$-N-acetylglucosamine (O-GlcNAc) modification onto the serine and threonine residues of nucleocytosolic proteins $[17,18]$. It has been shown in multiple systems that the elevation of O-GlcNAc levels is sufficient to cause insulin resistance [19-24]. Furthermore, the overexpression of OGT in the peripheral tissues of mice results in both glucose disposal defects and hyperleptinemia providing further evidence that the O-GlcNAc modification causes insulin resistance and the dysregulation of adipocytokine expression [21]. We have previously characterized and quantified the secretome of rodent adipocytes during insulin resistance generated by either directly or indirectly modulating O-GlcNAc levels [25]. We use a similar approach in this study. Insulin resistance is induced in primary human adipocytes by either the classical method of chronic hyperinsulinemia and hyperglycemia or by directly elevating O-GlcNAc levels using O-GlcNAcase (OGA) pharmacological inhibitors. To identify and quantify the secretome we use a proteomic approach with reverse phase (RP) liquid chromatography-nanospray-tandem mass spectrometry (LC-NS-MS/MS). We identify a total of 190 secreted proteins from primary human adipocytes. We compare the relative abundance of the adipocytokines during insulin responsive versus insulin resistant conditions using spectral counts. We report that 20 proteins are upregulated and 4 are downregulated when primary human adipocytes are shifted from insulin sensitive to insulin resistant conditions.

Glycosylation is one of the most common post-trans lational modifications (PTMs) of proteins, especially of secreted proteins [26-34]. In certain disease states, the glycome and the enzymes responsible for the glycan complexity can be altered $[35,36]$. It has been suggested that the increased pool of UDP-GlcNAc during excessive nutrient flux alters glycosyltransferase activity and the degree of N-glycan branching [37]; however, another study reported no change in complex glycosylation during elevated HBP flux [38]. Determining the glycome in different disease states is important for the future identification of structure-function relationships and to discover targets for diagnostic biomarkers $[25,39,40]$. The glycome of human adipose tissue has not been previously described. Glycan analysis is challenging due to the diversity of possible structures and their low abundance [35,41-49]. We use several strategies to identify, site-map, and quantify glycans from adipose tissue using mass spectrometry (MS). We characterize a total of $155 \mathrm{~N}$-linked glycans and 29 O-linked glycans using MS/MS spectra by total ion mapping (TIM) scan. Predominant N-linked and O-linked glycans can be quantified by ${ }^{13} \mathrm{C}$ isotopic labeling by permethylation using heavy or light iodomethane $\left({ }^{13} \mathrm{CH}_{3} \mathrm{I}\right.$ and $\left.{ }^{12} \mathrm{CH}_{3} \mathrm{I}\right)$ and isobaric pairs of iodomethane $\left({ }^{13} \mathrm{CH}_{3} \mathrm{I}\right.$ or $\left.{ }^{12} \mathrm{CH}_{2} \mathrm{DI}\right)(48,49)$. A total of $48 \mathrm{~N}$-linked glycans and 12 O-linked glycans are compared between the insulin responsive condition and both insulin resistance conditions by calculating the ${ }^{13} \mathrm{C} /{ }^{12} \mathrm{C}$ ratios from the sum of peak areas and from non-labeled prevalence rates. We also identify $91 \mathrm{~N}$-glycosylation sites derived from 51 secreted proteins using the PNGase F digestion in ${ }^{18} \mathrm{O}$ water using a parent mass list method.

Herein, we describe the secretome and glycome of primary human adipocytes during insulin sensitive and insulin resistant condition. Given the important physiological roles of adipocytokines in maintaining whole-body energy homeostasis, the characterization of the primary human adipocyte secretome during insulin resistance could provide novel markers and/or therapeutic targets for the onset of insulin resistance.

\section{Experimental procedures}

\section{Tissue culture and conditioned cell treatments}

Cryopreserved human subcutaneous preadipocytes (number of donors: 6-7, gender of donors: female, average age: 39, and average BMI: 27.32) were purchased from Zen-Bio, Inc. (Research Triangle Park, NC). The adipose tissue culture protocols of the maintenance and differentiation from preadipocytes to adipocytes were based on Zen-Bio instruction manual (ZBM0001.01). Briefly approximately $6.7 \times 10^{5}$ cells were cultured in a T-75 $\mathrm{cm}^{2}$ culture flask using preadipocyte medium (PM-1, Zen-Bio, Inc.), under a humidified atmosphere containing $5 \% \mathrm{CO}_{2}$ in air at $37^{\circ} \mathrm{C}$ until they were $85-90 \%$ confluent, and then were trypsinized for 5 minutes at $37^{\circ} \mathrm{C}$. After neutralization and centrifugation steps, the cell pellet was resuspended in PM-1 and seeded at an average density of $2.67 \times 10^{4} \mathrm{cells} / \mathrm{cm}^{2}$ in $10-\mathrm{cm}$ cell culture dishes for differentiation. 2 days after the cells reached confluence (referred to as day 0 ), the medium was replaced with adipocyte differentiation medium (DM-2, Zen-Bio, Inc.). On day 7, the DM-2 was removed and the cells were maintained in adipocyte maintenance medium (AM-1, Zen-Bio, Inc.). The medium was changed every 3 days. On day 15 , at which the majority of the cells contained large lipid droplets, the AM-1 medium 
was replaced with low glucose DMEM (Cellgro, Mediatech, Inc.) containing 10\% FBS (GIBCO, Invitrogen) and antibiotics (100 units/mL penicillin and $100 \mu \mathrm{g} / \mathrm{mL}$ streptomycin (P/S), Cellgro, Mediatech, Inc.). The medium was changed every 2 days until treatments were applied. On day 20, adipocytes were treated with different conditions, either (1) low glucose (LG) (LG, DMEM containing 10\% FBS and $\mathrm{P} / \mathrm{S}$ ), (2) insulin (100 nM, human, Roche) in high glucose (HG + INS) (HG, DMEM containing 10\% FBS and $\mathrm{P} / \mathrm{S})$, (3) PUGNAc $(100 \mu \mathrm{M}, \mathrm{TRC}$, Inc.) in low glucose (LG + PUGNAc) (LG, DMEM containing 10\% FBS and P/S), or (4) GlcNAcstatin (20 nM, kind gift from Dr. Daan van Aalten) in low glucose (LG + PUGNAc) (LG, DMEM containing $10 \% \mathrm{FBS}$ and $\mathrm{P} / \mathrm{S})$. After the first $24 \mathrm{~h}$ of incubation, the cells were washed five times (for mass spectrometry analysis) or 3 times (for immunoblotting) with low or high glucose serum-free DMEM without antibiotics and incubated for 15 min during the last rinse. After the final wash, the treatment conditions were added as above except no serum was added and the HG + INS treatment was changed to $1 \mathrm{nM}$ Insulin. The cells and media were harvested after $16 \mathrm{~h}$ of incubation.

\section{Secreted protein sample preparation}

The conditioned media was harvested with extreme care not to disrupt underlying cells and then centrifuged once at $1800 \mathrm{rpm}$, at $4^{\circ} \mathrm{C}$ for $7 \mathrm{~min}$. The supernatant was filtered using $1 \mu \mathrm{m}$ syringe filters (PALL). The samples were then centrifuged again at $30000 \times \mathrm{g}$, at $4^{\circ} \mathrm{C}$ for $30 \mathrm{~min}$. The samples were then transferred to equilibrated spin columns (Centriprep YM-3, Amicon, Millipore) and bufferexchanged at $2800 \times g$, at $4{ }^{\circ} \mathrm{C}$ into $40 \mathrm{mM}$ ammonium bicarbonate $\left(\mathrm{NH}_{4} \mathrm{HCO}_{3}\right)$ in the presence of $1 \mathrm{mM}$ dithiothreitol (DTT, Fisher Scientific) and concentrated. The samples were either quantified and prepared for immunoblotting or were denatured with $1 \mathrm{M}$ urea (Sigma), reduced with $10 \mathrm{mM}$ DTT for $1 \mathrm{~h}$ at $56^{\circ} \mathrm{C}$, carboxyamidomethylated with $55 \mathrm{mM}$ iodoacetamide $\left(\mathrm{ICH}_{2} \mathrm{CONH}_{2}\right.$, Sigma) in the dark for $45 \mathrm{~min}$, and then digested with $4 \mu \mathrm{g}$ of trypsin (Promega) in $40 \mathrm{mM} \mathrm{NH} \mathrm{HCO}_{3}$ overnight at $37^{\circ} \mathrm{C}$. After digestion, the peptides were acidified with $200 \mu \mathrm{L}$ of $1 \%$ trifluoroacetic acid (TFA). Desalting was subsequently performed with C18 spin columns (Vydac Silica C18, The Nest Group, Inc.) and the resulting peptides were dried down in a Speed Vac and stored at $-20^{\circ} \mathrm{C}$ until analysis. For the subset of samples to be analyzed for $\mathrm{N}$-linked glycosylation, peptides were resuspended in $19 \mu \mathrm{L}$ of ${ }^{18} \mathrm{O}$ water $\left(\mathrm{H}_{2}^{18} \mathrm{O}\right.$, 95\%, Cambridge Isotope Laboratories, Inc.) and $1 \mu \mathrm{L}$ of $\mathrm{N}$-Glycosidase F (PNGase F, Prozyme) and allowed to incubate for $18 \mathrm{~h}$ at $37^{\circ} \mathrm{C}$. Peptides were dried back down and resuspended in $50 \mu \mathrm{L}$ of $40 \mathrm{mM} \mathrm{NH} \mathrm{NHCO}_{3}$, with $1 \mu \mathrm{g}$ of trypsin for $4 \mathrm{hr}$, to remove any possible C-terminal incorporation of ${ }^{18} \mathrm{O}$ from residual trypsin activity, and then dried down and stored at $-20^{\circ} \mathrm{C}$ until analysis.

\section{Whole cell extracts and western blots}

After culture medium was removed for secreted proteins analysis, the cell monolayer was washed twice with $10 \mathrm{ml}$ of ice-cold PBS and scraped in the presence of $1 \mathrm{ml}$ PBS plus protease inhibitors. After removing PBS by centrifugation at $6,000 \times g$ for $5 \mathrm{~min}$ at $4^{\circ} \mathrm{C}$, the pellet was snap frozen and stored at $-80^{\circ} \mathrm{C}$. To prepare lysate for immunoblotting, the pellets were lysed in $20 \mathrm{mM}$ Tris $\mathrm{pH} 7.5,150 \mathrm{mM}$ $\mathrm{NaCl}, 1 \mathrm{mM}$ EDTA, 1\% NP-40, 1:100 protease inhibitor cocktail set V, EDTA-free (Calbiochem), and 1 uM PUGNAc. Protein concentration was determined using the Pierce BCA Protein Assay Kit (Thermo Scientific) and samples were boiled in Laemli sample buffer. The immunoblots were performed essentially as described [50] using CTD 110.6 (for O-GlcNAc modified proteins) and ERK-2 (as a positive control for loading) antibodies. For secreted protein immunoblotting, the media concentration was quantified using the Bradford method and verified by Coomassie staining. Equal amounts of protein were separated by SDS-PAGE with Tris- $\mathrm{HCl}$ precast minigels (Bio-Rad) and transferred to nitrocellulose membranes for Western blot analysis. After blocking for at least 1 hour, membranes were incubated with the appropriate primary antibody, anti-SPARC (Abcam) or antiChitinase-3-like protein 1 (R\&D Systems) overnight at $4^{\circ} \mathrm{C}$. Membranes were incubated with the appropriate horseradish peroxidase-coupled secondary antibodies for 1 hour, followed by extensive washing and Pierce ECL detection.

\section{Protein extracts for glycan analysis}

After the conditioned media was collected, the adipocytes were immediately washed twice with ice-cold PBS and harvested by scraping for glycan analysis. The cells were centrifuged at $12,000 \times g$, at $4^{\circ} \mathrm{C}$ for $15 \mathrm{~min}$ to remove the supernatant and debris, then snap frozen and stored at $-80^{\circ} \mathrm{C}$ until analysis. After the cell pellets thawed on ice, the samples were subjected to Dounce homogenization in ice-cold $100 \%$ methanol. The homogenized samples were delipidated by two solvent extractions using a mixture of chloroform/methanol/water $(4: 8: 3, \mathrm{v} / \mathrm{v} / \mathrm{v})$ and rocking for $3 \mathrm{~h}$ at room temperature as described previously [35,40]. The emulsion was centrifuged at $2800 \times g$ for $15 \mathrm{~min}$ at $4^{\circ} \mathrm{C}$ to remove the supernatant. The pellets were resuspended in an acetone/water $(10: 1, \mathrm{v} / \mathrm{v})$ mixture and incubated on ice for $15 \mathrm{~min}$ for washing. The protein pellets were collected by centrifugation and dried on a heating module at $45^{\circ} \mathrm{C}$ under a mild nitrogen stream (ReactiTherm $^{\mathrm{Tw}}$ and Reacti-Vap ${ }^{\mathrm{Tx}}$, Pierce). The dried protein powder was weighed and stored at $-20^{\circ} \mathrm{C}$ until analysis.

\section{Preparation of $\mathrm{N}$-linked glycans}

Three $\mathrm{mg}$ of the protein powder was resuspended in $200 \mu \mathrm{L}$ of $40 \mathrm{mM} \mathrm{NH}_{4} \mathrm{HCO}_{3}$ by sonication followed by 
boiling at $100^{\circ} \mathrm{C}$ for $5 \mathrm{~min}$. After cooling to room temperature, $25 \mu \mathrm{L}$ of trypsin $\left(2 \mathrm{mg} / \mathrm{mL}\right.$ in $40 \mathrm{mM} \mathrm{NH}_{4} \mathrm{HCO}_{3}$, Sigma) and chymotrypsin $\left(2 \mathrm{mg} / \mathrm{mL}\right.$ in $40 \mathrm{mM} \mathrm{NH}_{4} \mathrm{HCO}_{3}$, Sigma) were added. The samples were denatured with $250 \mu \mathrm{L}$ of $2 \mathrm{M}$ urea in $40 \mathrm{mM} \mathrm{NH}_{4} \mathrm{HCO}_{3}$, leading to a final concentration of $1 \mathrm{M}$ urea, and incubated overnight (18 h) at $37^{\circ} \mathrm{C}$. After digestion, the peptide samples were centrifuged and $10 \mu \mathrm{L}$ of the supernatant was collected for protein quantification. The peptide concentrations were measured using a Pierce BCA Protein Assay Kit (Thermo Scientific). The samples were boiled at $100^{\circ} \mathrm{C}$ for $5 \mathrm{~min}$ and then acidified by adding $500 \mu \mathrm{L}$ of $10 \%$ acetic acid $(\mathrm{AcOH})$ to deactivate proteases. The samples were loaded onto an equilibrated C18 extraction column (BakerBond ${ }^{\mathrm{m}}$, J.T.Baker), washed with $1 \mathrm{~mL}$ of $5 \% \mathrm{AcOH}$ three times, and then eluted stepwise using $1 \mathrm{~mL}$ of $20 \%$ isopropanol in $5 \% \mathrm{AcOH}, 40 \%$ isopropanol in $5 \% \mathrm{AcOH}$, and $100 \%$ isopropanol. The resulting glycopeptides were dried in a Speed Vac, resuspended in $48 \mu \mathrm{L} 1 \times$ PNGase F reaction buffer and $2 \mu \mathrm{L}$ PNGase F and incubated for $18 \mathrm{~h}$ at $37^{\circ} \mathrm{C}$. Following PNGase F digestion, released oligosaccharides were separated by the C18 extraction column. The mixture was reconstituted in 5\% $\mathrm{AcOH}$ and loaded onto an equilibrated C18 extraction column. The N-linked oligosaccharides were eluted using $1 \mathrm{~mL}$ of $5 \% \mathrm{AcOH}$ three times and then collected and dried using a Speed Vac for subsequent permethylation.

\section{Preparation of O-linked glycans}

O-linked oligosaccharides were released by reductive $\beta$ elimination then purified by a cation exchange resin. Three $\mathrm{mg}$ of delipidated protein powder was weighed and transferred into a clean glass tube. $500 \mu \mathrm{L}$ of $50 \mathrm{mM}$ sodium hydroxide $(\mathrm{NaOH})$ and $500 \mu \mathrm{L}$ of alkaline borohydride solution (a mixture of $2 \mathrm{M}$ sodium borohydride $\left(\mathrm{NaBH}_{4}\right.$, Sigma-Aldrich) in $50 \mathrm{mM} \mathrm{NaOH}$ leading to a final concentration of $1 \mathrm{M} \mathrm{NaBH}_{4}$ ) were added to the tube. The mixture was incubated for $16 \mathrm{~h}$ at $45^{\circ} \mathrm{C}$ on the heating block and the reaction was stopped by the addition of $10 \%$ $\mathrm{AcOH}$ with vortexing. The acidified mixture was loaded onto an equilibrated cation exchange resin cartridge (AG $50 \mathrm{~W}-\mathrm{X} 8$, Bio-Rad) with 5\% AcOH. O-linked glycans were eluted with $6 \mathrm{~mL}$ of $5 \% \mathrm{AcOH}$ and then dried in a Speed Vac. The sample was resuspended in $1 \mathrm{~mL}$ methanol/ glacial acetic acid $(9: 1, \mathrm{v} / \mathrm{v})$ solution and dried on the heating module at $45^{\circ} \mathrm{C}$ under a mild nitrogen stream to remove borates for subsequent permethylation.

\section{Permethylation of glycans}

To facilitate analysis of oligosaccharides by mass spectrometry, the released oligosaccharide mixtures were permethylated as described previously [35,39,51]. Briefly, glycans were resuspended in $200 \mu \mathrm{L}$ of anhydrous dimethyl sulfoxide (DMSO, Sigma-Aldrich) and $250 \mu \mathrm{L}$ of fresh dehydrated
$\mathrm{NaOH} / \mathrm{DMSO}$ reagent (mixture of $50 \mathrm{mg} \mathrm{NaOH}$ in $2 \mathrm{~mL}$ of anhydrous DMSO). After sonication and vortexing under nitrogen gas, $100 \mu \mathrm{L}$ of ${ }^{12} \mathrm{C}$ or ${ }^{13} \mathrm{C}$-iodomethane $\left({ }^{12} \mathrm{CH}_{3} \mathrm{I}\right.$ and ${ }^{13} \mathrm{CH}_{3} \mathrm{I}, 99 \%$ of ${ }^{13} \mathrm{C}$, Sigma-Aldrich) was added and the mixtures were vortexed vigorously for $5 \mathrm{~min} .2 \mathrm{~mL}$ of distilled water was added to the samples and the excess iodomethane was removed by bubbling with a nitrogen stream. Two $\mathrm{mL}$ of dichloromethane $\left(\mathrm{CH}_{2} \mathrm{Cl}_{2}\right.$, Sigma-Aldrich) was added. After vigorous mixing and phase separation by centrifugation, the upper aqueous layer was removed and discarded. The nonpolar organic phase was then extracted 4 times with distilled water. Dichloromethane was evaporated on the heating module at $45^{\circ} \mathrm{C}$ with a mild nitrogen stream. The permethylated glycans were dissolved in adjusted volumes $(15-30 \mu \mathrm{L})$ of $100 \%$ methanol according to the results of the protein assay. The ${ }^{12} \mathrm{C}$ and ${ }^{13} \mathrm{C}$-labeled permethylated glycans were mixed in the same proportion for each experimental condition before analysis.

\section{Analysis using mass spectrometry}

For proteome analysis of secreted proteins by liquid chromatography tandem mass spectrometry (LC-MS/MS), the peptides were resuspended with $19.5 \mu \mathrm{L}$ of mobile phase $\mathrm{A}$ ( $0.1 \%$ formic acid, FA, in water) and $0.5 \mu \mathrm{L}$ of mobile phase B (80\% acetonitrile, ACN, and $0.1 \%$ formic acid in water) and filtered with $0.2 \mu \mathrm{m}$ filters (Nanosep, PALL). The samples were loaded off-line onto a nanospray tapered capillary column/emitter $\left(360 \times 75 \times 15 \mu \mathrm{m}\right.$, PicoFrit ${ }^{\circ}$, New Objective) that was self-packed with C18 reverse phase (RP) resin $(8.5 \mathrm{~cm}$, Waters) in a nitrogen pressure bomb for $10 \mathrm{~min}$ at 1000 psi $(\sim 5 \mu \mathrm{L}$ load $)$. The samples were then separated via a 160 min linear gradient of increasing mobile phase $\mathrm{B}$ at a flow rate of $\sim 200 \mathrm{~nL} / \mathrm{min}$ directly into the mass spectrometer. One-dimensional LC-MS/MS analysis was performed using a linear ion trap and an Orbitrap mass spectrometer (LTQ and LTQ Orbitrap XL, Thermo Fisher Scientific Inc., San Jose, CA) equipped with a nanoelectrospray ion source at $2.0 \mathrm{kV}$ capillary voltage and $200^{\circ} \mathrm{C}$ capillary temperature. For secretome analysis, a full ITMS (Ion trap mass spectrometry) spectrum in positive ion and profile mode was collected at $300-2000 \mathrm{~m} / \mathrm{z}$ followed by $8 \mathrm{MS} / \mathrm{MS}$ events on the 8 most intense peaks with enabled dynamic exclusion using a repeat count of 2 , a maximum exclusion list size of 100, and an exclusion duration of $30 \mathrm{~s}$. Each MS/MS scan event was followed by CID (34\% normalized collision energy), 0.25 activation $\mathrm{Q}$, and $30.0 \mathrm{~ms}$ activation time. For N-liked glycosylation site mapping, a full FTMS (Fourier transform mass spectrometry) spectrum, typically recorded at 60000 resolution in positive ion and profile mode, was acquired at $300-2000 \mathrm{~m} / \mathrm{z}$ followed by 5 data dependent MS/MS spectra of ITMS on the most intense ion peaks from parent mass list following CID (36\% normalized collision energy), 0.25 activation $\mathrm{Q}$, and $30.0 \mathrm{~ms}$ activation time. Dynamic 
exclusion was set at a repeat count of 2 , a maximum exclusion list of 100, and an exclusion duration of $60 \mathrm{~s}$.

For glycome analysis by direct infusion nanospray MS, permethylated glycans were dissolved by combining $15 \mu \mathrm{L}$ of the isotopically mixed sample in $100 \%$ methanol plus $35 \mu \mathrm{L} 1 \mathrm{mM} \mathrm{NaOH}$ in 50\% methanol. They were infused directly into a linear ion trap and an Orbitrap mass spectrometer using a nanospray ion source with a fused-silica emitter $\left(360 \times 75 \times 30 \mu \mathrm{m}\right.$, SilicaTip ${ }^{\mathrm{Tn}}$, New Objective) at $2.0 \mathrm{kV}$ capillary voltage, $200^{\circ} \mathrm{C}$ capillary temperature, and a syringe flow rate of $0.4 \mu \mathrm{L} / \mathrm{min}$. The full ITMS spectra and FTMS spectra, typically recorded at 60000 resolution in positive ion and profile mode, were collected at 400$2000 \mathrm{~m} / \mathrm{z}$ for $30 \mathrm{~s}$ with 5 microscans and 150 maximum injection times (ms). The centroid MS/MS spectra following collision-induced dissociation (CID) were obtained from 400 to $2000 \mathrm{~m} / \mathrm{z}$ at $34 \%$ and $28 \%$ normalized collision energy for $\mathrm{N}$ - and O-linked glycans, respectively, 0.25 activation $\mathrm{Q}$, and $30.0 \mathrm{~ms}$ activation time by total ion mapping (TIM). Parent mass step size and isolation width were set at $2.0 \mathrm{~m} / \mathrm{z}$ and $2.8 \mathrm{~m} / \mathrm{z}$, respectively, for automated MS/MS spectra with TIM scans.

\section{Data analysis}

The resulting proteomic data was searched against a target nonredundant human (Homo sapiens, 5-2-07) database including the common contaminants database obtained from the human International Protein Index (IPI) protein sequence database (European Bioinformatics Institute, ftp:// ftp.ebi.ac.uk/pub/databases/IPI) using the TurboSequest algorithm (BioWorks 3.3.1 SP1, Thermo Fisher Scientific Inc.) $[52,53]$. It was also searched against a decoy human database to determine statistically relevant peptide identification. DTA files were generated for spectra with a threshold of 15 ions and a TIC of $2 \mathrm{e}^{3}$ over a range of $[\mathrm{MH}]^{+}=600-4000$ for only IT data. The SEQUEST parameters were set to allow $2.0 \mathrm{Da}$ ( $20 \mathrm{ppm}$ for FT) of precursor ion mass tolerance and $0.5 \mathrm{Da}$ of fragment ion tolerance with monoisotopic mass. Only strict tryptic peptides were allowed with up to two missed internal cleavage sites. Dynamic mass increases of 15.99 and 57.02 Da (15.9949 and 57.0215 Da for FT) were allowed for oxidized methionine and alkylated cysteine, respectively. In the cases where sites of N-linked glycosylation were investigated with PNGase $\mathrm{F}$ and ${ }^{18} \mathrm{O}$ water, a dynamic mass increase of 3.0 Da (2.9883 Da for FT) was allowed for Asn residues [54]. The masses were selected between $300-2000 \mathrm{~m} / \mathrm{z}$ at each charge state and 7352 total masses were obtained for parent mass list. Each sample was analyzed by four LC-MS/ MS runs with different parent mass list up to 2000 because of maximum number of parent masses for FTMS and mass complexity. The results from shotgun method and parent mass list method were combined and filtered at $\geq 0.60$ Final Score (Sf). For relative protein quantification, the identified peptides and proteins were statistically validated between the target and decoy database search results, and protein ratios were determined by normalized spectral counts using ProteoIQ 1.1 (Premiere BioSoft). Proteins identified by two peptides were only considered to be statistically significant at less than $1 \%$ protein false discovery rate (FDR) using the ProValT algorithm as implemented in ProteoIQ [55,56]. From the results, the subcellular location of secreted proteins was manually determined for each protein from the Human Protein Reference Database (http://www.hprd.org/), Information Hyperlinked Over Proteins (iHOP, http:// www.ihop-net.org/UniPub/iHOP/) and the UniProtKB/ Swiss-Prot (http://www.ebi.ac.uk/uniprot) databases. The functional categories of secretome were annotated by the Ingenuity Pathways Analysis program (IPA, Ingenuity Systems, Inc.).

The $\mathrm{N}$ - and O-linked glycans released from the protein power of adipocytes were analyzed by full MS following permethylation and subsequent MS/MS fragmentations for specific glycan structures. We used GlycoWorkbench (http://glycomics.ccrc.uga.edu/eurocarb/gwb/home.action) to facilitate manually interpretation of the glycan structures from the MS/MS spectra by TIM scan. The areas of each isotopic peak were calculated by their Gaussian distribution and then averaged to compare the relative abundance of each glycan between different samples. The ratio of peak areas from isotopic permethylation defined the relative abundance of each glycan.

\section{Results}

Insulin resistance and global O-GIcNAc levels in primary human adipocytes

Treatment with hyperglycemia and chronic insulin or normoglycemia and the pharmacological OGA inhibitor, PUGNAc, result in the global elevation of O-GlcNAc modified nucleocytosolic proteins and insulin resistance in rodent adipocytes $[19,57]$. We tested these conditions as well as treatment with a more specific OGA inhibitor, GlcNAcstatin, in primary human adipocytes [58]. Cryopreserved human preadipocytes were expanded and differentiated into mature adipocytes before treatment as described in Materials and Methods. Figure 1 shows that when compared to normoglycemia (LG), treatment with OGA inhibitors (LG + PUGNAc or LG + GlcNAcstatin) or treatment with hyperglycemia and hyperinsulinemia (HG + INS) raises global O-GlcNAc levels as measure by immunoblotting with an O-GlcNAc specific antibody. In a previous study using rodent adipocytes, we characterized and quantified the secretome and glycome during insulin sensitive and insulin resistant conditions induced by indirectly (HG + INS) or directly (LG + PUGNAc) modulating O-GlcNAc levels. We found that many secreted proteins were up or down-regulated upon the induction of insulin resistance. Here we took a parallel approach to ask the 


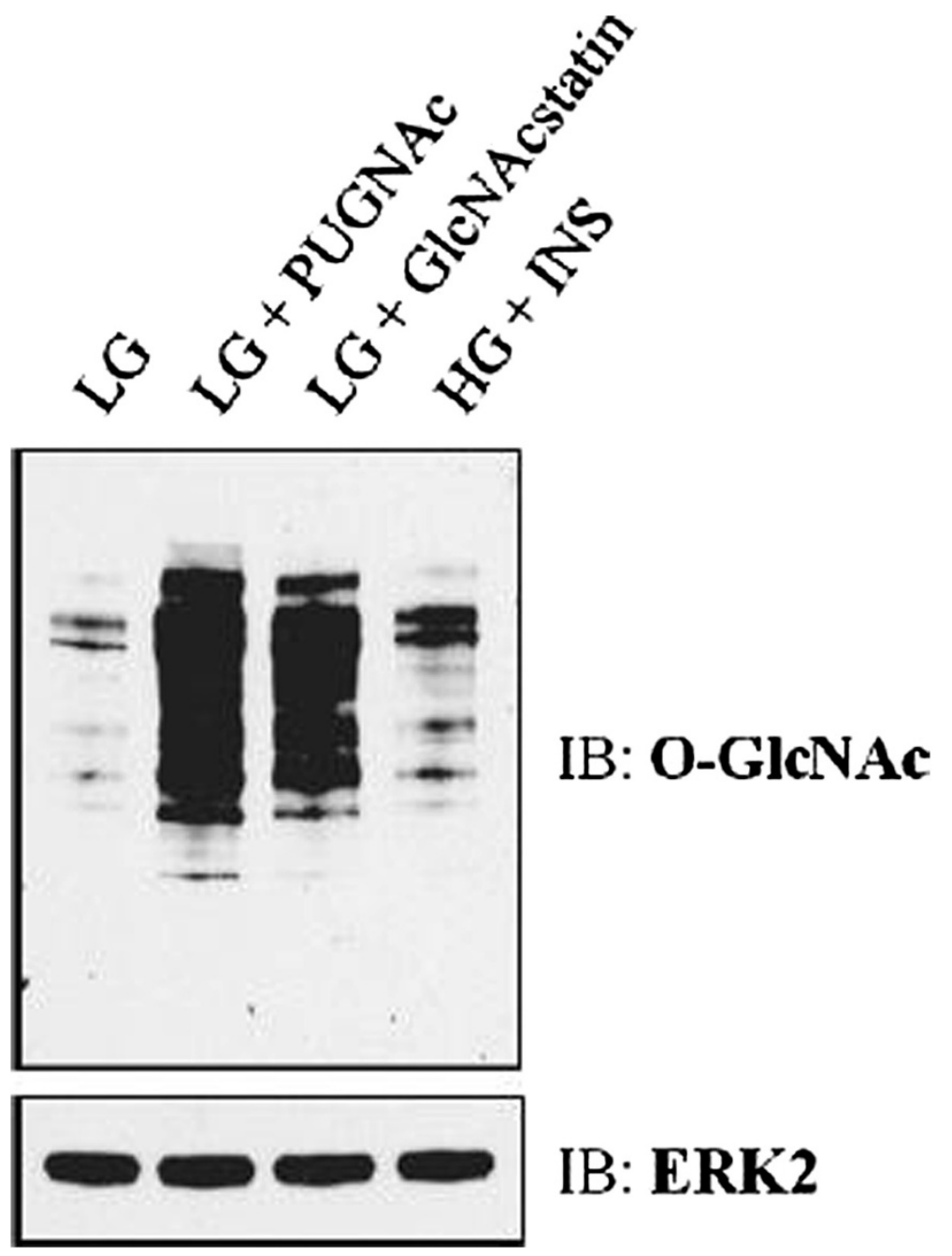

Figure 1 Detection of O-GIcNAc levels in primary human adipocytes. Global O-GlcNAc levels are elevated in three insulin resistant conditions generated by low glucose plus PUGNAc (LG + PUGNAc), low glucose plus GlcNAcstatin (LG + GlcNAcstatin), or high glucose plus chronic insulin exposure $(\mathrm{HG}+\mathrm{INS})$.

same question using primary human adipocytes. As shown in Figure 2, after treatment both the cells and conditioned media were harvested. Before the final 16 hour serum-free treatment incubation, the cells were washed five times with serum-free media to remove any traces of serum. This greatly reduced the complexity of the conditioned media. The conditioned media was buffer exchanged and concentrated before being processed for analysis by LC-MS/MS. Cells were collected and delipidated as in Materials and Methods. Protein was digested and prepared for either Nglycan or O-glycan analysis (Figure 2).

\section{Characterization of the primary human adipose tissue secretome by LC-MS/MS}

The mass spectra from 24 mass spectrometric analyses were searched against a target nonredundant human database as well as a decoy human database using SEQUEST.
Proteins identified by at least two non-redundant peptides with less than a 1\% FDR were identified using ProteoIQ. Secreted proteins were manually determined by a reference search as described in Materials and Methods. Using these criteria, a total of 190 secreted proteins were identified. Table 1 shows the complete list of the 173 secreted proteins identified by at least 2 unique peptides. 17 of the secreted proteins identified based on a single peptide are presented in Supplemental Table 1 (Additional file 1: Table S1). Figure 3 shows the proportion of the secretome in each of the 9 main functional categories assigned by Ingenuity Pathways Analysis. The most highly represented categories are enzyme, peptidase, and other protein.

Quantification of the primary human adipocyte secretome Several mass spectrometry techniques can be used for quantitative analysis. Both isotopic and non-isotopic 


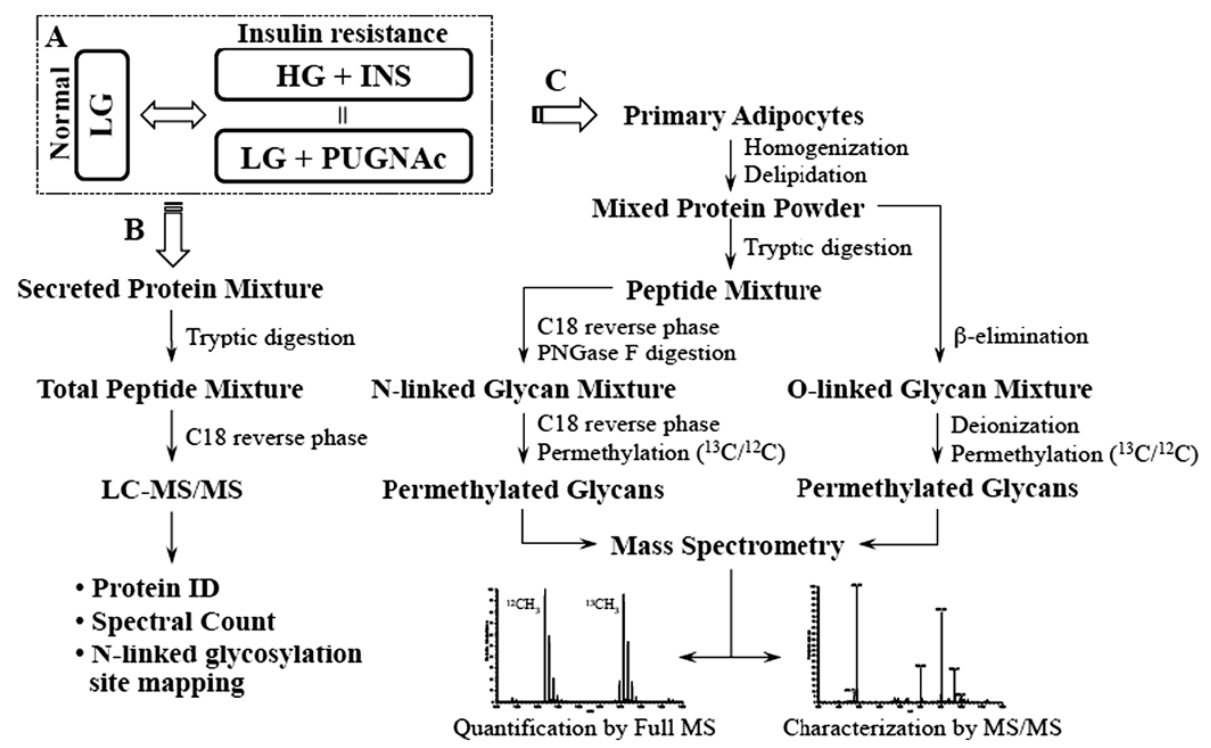

Figure 2 Schematic flow diagram of the experimental procedure. (A) Primary human adipocytes are treated with insulin responsive (LG, normoglycemic) or two insulin resistance generating conditions (HG + INS and LG + PUGNAc). (B) Identification and quantification of the secretory proteome and N-linked glycosylation site-mapping from the conditioned media of treated primary human adipocytes (C) Characterization and quantification of $\mathrm{N}$ - and O-linked glycans from a whole protein extract of treated primary human adipocytes.

labeling are commonly used to provide quantitative analysis of proteins in complex protein samples [59-67]. For non-isotopic or label-free MS-based quantitative analysis, ion chromatogram intensity or observed peptide spectral counts are compared using quantitative software tools [68-76]. Peptide spectral counts quantification relies on the association between protein abundance and the number of MS/MS spectra identifying each protein. For this study, we used three biological replicates of conditioned media samples, which differed in complex proteome profiles and relative number of normalized spectral counts. For each of the biological replicates, prepared conditioned media from three treatment groups (LG, LG + PUG, HG + INS) was subjected to two technical replicates of reverse phase LC-MS/MS. All together, a total of 18 LC-MS/MS experiments were performed. SEQUEST was used to search MS data files from each LC-MS/MS run against a forward and reversed human database to calculate a FDR. ProteoIQ was used to cluster the peptides to their assigned proteins and to gather normalized spectral counts for proteins identified at less than a $1 \%$ FDR and assigned by at least two non-redundant peptides. Spectral counts were normalized for each technical replicate. For each biological replicate the normalized spectral counts were averaged followed and then the comparative ratios between the two insulin resistant conditions and the insulin responsive condition were calculated. Finally, the comparative ratios were averaged between all of the biological replicates. We set the threshold for reporting statistically significant differences at $\geq 150 \%$ (1.5-fold), an average of $\geq 5$ total spectral counts, and an average of $\geq 3$ normalized spectral counts for each treatment group. We identified 20 human adipocytokines whose secretion levels were upregulated and 4 proteins that were downregulated by at least 1.5 -fold by the transition from the insulin sensitive condition to both insulin resistant conditions (Table 2). We also identified 28 and 8 proteins that were upregulated or downregulated, respectively, in the transition from insulin sensitive to one of the insulin resistant conditions (Additional file 1: Table S2).

To confirm the validity of the ratio that we used for statistical significance, we used the orthogonal method of immunoblotting. We confirmed that the regulation we observed in the proteomic experiment with immunoblotting for two proteins whose levels changed by only 1.5 -fold in at least one of the insulin resistant conditions as determined by proteomics. In addition, we used cells where insulin resistance was induced using a more specific OGA inhibitor, GlcNAcstatin, to confirm the regulation we observed by using the less specific OGA inhibitor, PUGNAc $[58,77]$. Figure 4 shows that both SPARC and Chitinase-3-like protein 1 are upregulated in both insulin resistant conditions as determined by immunoblotting, which confirms our proteomic experiment.

$\mathrm{N}$-glycan site-mapping of the human adipocyte secretome Many secreted proteins are modified by N-glycans. During disease states, the glycoforms of these proteins may change and have the potential to be used as disease biomarkers. Since the glycome of adipocytes is not well-defined, we determine sites of $\mathrm{N}$-linked glycosylation on secreted adipocytokines as an initial step in biomarker discovery. The tryptic peptides generated from conditioned media were 
Table 1 Total secreted proteins from human dispose tissue by LC-MS/MS

\begin{tabular}{|c|c|c|c|}
\hline No. & Protein ID & Identifed proteins & Subcellular location $^{\mathrm{a}}$ \\
\hline 1 & Q92484 & Acid sphingomyelinase-like phosphodiesterase $3 a$ & Extracellular \\
\hline 2 & P07108 & Acyl-CoA-binding protein & Cytoplasm \\
\hline 3 & Q8IUX7 & Adipocyte enhancer-binding protein 1 & Membrane \\
\hline 4 & P01023 & Alpha-2-macroglobulin & Nucleus \\
\hline 5 & P06733 & Alpha-enolase & Extracellular \\
\hline 6 & P15144 & Aminopeptidase N & Cytoplasm \\
\hline 7 & P01019 & Angiotensinogen & Membrane \\
\hline 8 & P07355 & Annexin A2 & Extracellular \\
\hline 9 & P08758 & Annexin A5 & Membrane \\
\hline 10 & Q8NCW5 & Apolipoprotein A-I binding protein & Extracellular \\
\hline 11 & P05090 & Apolipoprotein D & Extracellular \\
\hline 12 & P02649 & Apolipoprotein E & Extracellular \\
\hline 13 & P15289 & Arylsulfatase A & Cytoplasm \\
\hline 14 & P61769 & Beta-2-microglobulin & Membrane \\
\hline 15 & P21810 & Biglycan & Extracellular \\
\hline 16 & P43251 & Biotinidase & Extracellular \\
\hline 17 & P55290 & Cadherin-13 & Membrane \\
\hline 18 & P27797 & Calreticulin & Cytoplasm \\
\hline 19 & O43852 & Calumenin & Cytoplasm \\
\hline 20 & P16870 & Carboxypeptidase E & Membrane \\
\hline 21 & P49747 & Cartilage oligomeric matrix protein & Extracellular \\
\hline 22 & P07858 & Cathepsin B & Cytoplasm \\
\hline 23 & P07339 & Cathepsin D & Cytoplasm \\
\hline 24 & P43235 & Cathepsin K & Cytoplasm \\
\hline 25 & P07711 & Cathepsin L & Cytoplasm \\
\hline 26 & Q9UBR2 & Cathepsin Z & Cytoplasm \\
\hline 27 & P36222 & Chitinase-3-like protein 1 & Extracellular \\
\hline 28 & Q15782 & Chitinase-3-like protein 2 & Extracellular \\
\hline 29 & Q59FG9 & Chondroitin sulfate proteoglycan 2 (versican) variant & Extracellular \\
\hline 30 & P10909 & Clusterin & Extracellular \\
\hline 31 & P02452 & Collagen alpha-1(I) chain & Extracellular \\
\hline 32 & P02458 & Collagen alpha-1(II) chain & Extracellular \\
\hline 33 & P02461 & Collagen alpha-1(III) chain & Extracellular \\
\hline 34 & P02462 & Collagen alpha-1(IV) chain & Extracellular \\
\hline 35 & P20908 & Collagen alpha-1(V) chain & Extracellular \\
\hline 36 & P12109 & Collagen alpha-1(VI) chain & Extracellular \\
\hline 37 & Q02388 & Collagen alpha-1(VII) chain & Extracellular \\
\hline 38 & P12107 & Collagen alpha-1(XI) chain & Extracellular \\
\hline 39 & Q99715 & Collagen alpha-1(XII) chain & Extracellular \\
\hline 40 & P39059 & Collagen alpha-1(XV) chain [Contains: Endostatin] & Extracellular \\
\hline 41 & P39060 & Collagen alpha-1(XVIII) chain [Contains: Endostatin] & Extracellular \\
\hline 42 & P08123 & Collagen alpha-2(I) chain & Extracellular \\
\hline 43 & P08572 & Collagen alpha-2(IV) chain [Contains: Canstatin] & Extracellular \\
\hline 44 & P05997 & Collagen alpha-2(V) chain & Extracellular \\
\hline
\end{tabular}


Table 1 Total secreted proteins from human dispose tissue by LC-MS/MS (Continued)

\begin{tabular}{|c|c|c|c|}
\hline 45 & P12110 & Collagen alpha-2(VI) chain & Extracellular \\
\hline 46 & P25940 & Collagen alpha-3( $\mathrm{V})$ chain & Extracellular \\
\hline 47 & P12111 & Collagen alpha-3(VI) chain & Extracellular \\
\hline 48 & P08253 & Collagenase (72 kDa type IV) & Extracellular \\
\hline 49 & P00736 & Complement $\mathrm{C} 1 \mathrm{r}$ subcomponent & Extracellular \\
\hline 50 & P09871 & Complement C1s subcomponent & Extracellular \\
\hline 51 & P01024 & Complement C3 & Extracellular \\
\hline 52 & P29279 & Connective tissue growth factor & Extracellular \\
\hline 53 & Q9Y240 & C-type lectin domain family 11 member A & Extracellular \\
\hline 54 & O75462 & Cytokine receptor-like factor 1 & Extracellular \\
\hline 55 & P07585 & Decorin & Extracellular \\
\hline 56 & Q07507 & Dermatopontin & Extracellular \\
\hline 57 & Q4VWZ6 & Diazepam binding inhibitor, splice form 1c & Cytoplasm \\
\hline 58 & Q9UBP4 & Dickkopf-related protein 3 & Extracellular \\
\hline 59 & Q14118 & Dystroglycan & Membrane \\
\hline 60 & Q13822 & Ectonucleotide pyrophosphatase/phosphodiesterase 2 & Membrane \\
\hline 61 & Q12805 & EGF-containing fibulin-like extracellular matrix protein 1 & Extracellular \\
\hline 62 & O95967 & EGF-containing fibulin-like extracellular matrix protein 2 & Extracellular \\
\hline 63 & Q9Y6C2 & EMILIN-1 & Extracellular \\
\hline 64 & Q9BXX0 & EMILIN-2 & Extracellular \\
\hline 65 & P61916 & Epididymal secretory protein E1 & Extracellular \\
\hline 66 & Q9Y2E5 & Epididymis-specific alpha-mannosidase & Cytoplasm \\
\hline 67 & Q16610 & Extracellular matrix protein 1 & Extracellular \\
\hline 68 & P08294 & Extracellular superoxide dismutase [Cu-Zn] & Extracellular \\
\hline 69 & P35555 & Fibrillin-1 & Extracellular \\
\hline 70 & Q53TP5 & Fibroblast activation protein, alpha subunit & Cytoplasm \\
\hline 71 & Q06828 & Fibromodulin & Extracellular \\
\hline 72 & P02751 & Fibronectin & Membrane \\
\hline 73 & P23142 & Fibulin-1 & Extracellular \\
\hline 74 & P98095 & Fibulin-2 & Extracellular \\
\hline 75 & Q9UBX5 & Fibulin-5 & Extracellular \\
\hline 76 & Q12841 & Follistatin-related protein 1 & Extracellular \\
\hline 77 & P16930 & Fumarylacetoacetase & Cytoplasm \\
\hline 78 & P09382 & Galectin-1 & Extracellular \\
\hline 79 & Q08380 & Galectin-3-binding protein & Membrane \\
\hline 80 & Q92820 & Gamma-glutamyl hydrolase & Cytoplasm \\
\hline 81 & P06396 & Gelsolin & Extracellular \\
\hline 82 & Q9UJJ9 & GlcNAc-1-phosphotransferase subunit gamma & Cytoplasm \\
\hline 83 & P07093 & Glia-derived nexin & Extracellular \\
\hline 84 & P04406 & Glyceraldehyde-3-phosphate dehydrogenase & Cytoplasm \\
\hline 85 & P35052 & Glypican-1 & Membrane \\
\hline 86 & P28799 & Granulins & Extracellular \\
\hline 87 & Q14393 & Growth-arrest-specific protein 6 & Extracellular \\
\hline 88 & P00738 & Haptoglobin & Extracellular \\
\hline 89 & P00739 & Haptoglobin-related protein & Extracellular \\
\hline
\end{tabular}


Table 1 Total secreted proteins from human dispose tissue by LC-MS/MS (Continued)

\begin{tabular}{|c|c|c|c|}
\hline 90 & O75629 & Human Protein CREG1 & Nucleus \\
\hline 91 & P17936 & Insulin-like growth factor-binding protein 3 & Extracellular \\
\hline 92 & P22692 & Insulin-like growth factor-binding protein 4 & Extracellular \\
\hline 93 & P24592 & Insulin-like growth factor-binding protein 6 & Extracellular \\
\hline 94 & Q16270 & Insulin-like growth factor-binding protein 7 & Extracellular \\
\hline 95 & O95965 & Integrin beta-like protein 1 & Unknown \\
\hline 96 & P19823 & Inter-alpha-trypsin inhibitor heavy chain $\mathrm{H} 2$ & Extracellular \\
\hline 97 & 014498 & ISLR & Extracellular \\
\hline 98 & Q08431 & Lactadherin & Extracellular \\
\hline 99 & Q8NHP8 & LAMA-like protein 2 & Extracellular \\
\hline 100 & Q59H37 & Laminin alpha 2 subunit isoform b & Extracellular \\
\hline 101 & Q16363 & Laminin subunit alpha-4 & Extracellular \\
\hline 102 & P07942 & Laminin subunit beta-1 & Extracellular \\
\hline 103 & P55268 & Laminin subunit beta-2 & Extracellular \\
\hline 104 & P11047 & Laminin subunit gamma-1 & Extracellular \\
\hline 105 & Q14767 & Latent-transforming growth factor beta-binding protein 2 & Extracellular \\
\hline 106 & Q99538 & Legumain & Cytoplasm \\
\hline 107 & Q07954 & Low-density lipoprotein receptor-related protein 1 & Membrane \\
\hline 108 & P51884 & Lumican & Extracellular \\
\hline 109 & P10619 & Lysosomal protective protein & Cytoplasm \\
\hline 110 & P13473 & Lysosome-associated membrane glycoprotein 2 & Membrane \\
\hline 111 & Q9Y4K0 & Lysyl oxidase homolog 2 & Extracellular \\
\hline 112 & P09603 & Macrophage colony-stimulating factor 1 & Extracellular \\
\hline 113 & Q9UM22 & Mammalian ependymin-related protein 1 & Nucleus \\
\hline 114 & P48740 & Mannan-binding lectin serine protease 1 & Extracellular \\
\hline 115 & P50281 & Matrix metalloproteinase-14 & Extracellular \\
\hline 116 & P01033 & Metalloproteinase inhibitor 1 & Extracellular \\
\hline 117 & P16035 & Metalloproteinase inhibitor 2 & Extracellular \\
\hline 118 & Q71SW6 & Muscle type neuropilin 1 & Membrane \\
\hline 119 & P14543 & Nidogen-1 & Extracellular \\
\hline 120 & Q14112 & Nidogen-2 & Extracellular \\
\hline 121 & Q02818 & Nucleobindin-1 & Cytoplasm \\
\hline 122 & Q9NRN5 & Olfactomedin-like protein 3 & Extracellular \\
\hline 123 & Q86UD1 & Out at first protein homolog & Unknown \\
\hline 124 & P26022 & Pentraxin-related protein PTX3 & Extracellular \\
\hline 125 & P62937 & Peptidyl-prolyl cis-trans isomerase A & Cytoplasm \\
\hline 126 & P23284 & Peptidylprolyl isomerase B & Cytoplasm \\
\hline 127 & Q15063 & Periostin & Extracellular \\
\hline 128 & P98160 & Perlecan & Membrane \\
\hline 129 & Q92626 & Peroxidasin homolog & Unknown \\
\hline 130 & P30086 & Phosphatidylethanolamine-binding protein 1 & Cytoplasm \\
\hline 131 & P55058 & Phospholipid transfer protein & Extracellular \\
\hline 132 & P36955 & Pigment epithelium-derived factor & Extracellular \\
\hline 133 & Q9BTY2 & Plasma alpha-L-fucosidase & Extracellular \\
\hline 134 & Q9Y646 & Plasma glutamate carboxypeptidase & Extracellular \\
\hline
\end{tabular}


Table 1 Total secreted proteins from human dispose tissue by LC-MS/MS (Continued)

\begin{tabular}{|c|c|c|c|}
\hline 135 & P05155 & Plasma protease C1 inhibitor & Extracellular \\
\hline 136 & P05121 & Plasminogen activator inhibitor 1 & Extracellular \\
\hline 137 & Q9GZP0 & Platelet-derived growth factor $D$ & Extracellular \\
\hline 138 & P07602 & Proactivator polypeptide [Contains: Saposin-A] & Extracellular \\
\hline 139 & Q15113 & Procollagen C-endopeptidase enhancer 1 & Extracellular \\
\hline 140 & Q02809 & Procollagen-lysine,2-oxoglutarate 5-dioxygenase 1 & Cytoplasm \\
\hline 141 & P07737 & Profilin-1 & Cytoplasm \\
\hline 142 & P41222 & Prostaglandin-H2 D-isomerase & Cytoplasm \\
\hline 143 & Q6UXB8 & Protease inhibitor 16 & Membrane \\
\hline 144 & P07237 & Protein disulfide-isomerase & Cytoplasm \\
\hline 145 & Q15084 & Protein disulfide-isomerase A6 & Cytoplasm \\
\hline 146 & P14618 & Pyruvate kinase isozymes M1/M2 & Cytoplasm \\
\hline 147 & Q96D15 & Reticulocalbin-3 & Cytoplasm \\
\hline 148 & Q99969 & Retinoic acid receptor responder protein 2 & Membrane \\
\hline 149 & O75326 & Semaphorin-7A & Membrane \\
\hline 150 & Q12884 & Seprase & Cytoplasm \\
\hline 151 & Q92743 & Serine protease HTRA1 & Extracellular \\
\hline 152 & P02787 & Serotransferrin & Extracellular \\
\hline 153 & P09486 & SPARC & Extracellular \\
\hline 154 & Q9BUD6 & Spondin-2 & Extracellular \\
\hline 155 & Q9BRK5 & Stromal cell-derived factor 4 & Cytoplasm \\
\hline 156 & 000391 & Sulfhydryl oxidase 1 & Cytoplasm \\
\hline 157 & P00441 & Superoxide dismutase $[\mathrm{Cu}-\mathrm{Zn}]$ & Cytoplasm \\
\hline 158 & Q9Y490 & Talin-1 & Membrane \\
\hline 159 & P24821 & Tenascin & Extracellular \\
\hline 160 & P22105 & Tenascin-X & Extracellular \\
\hline 161 & Q08629 & Testican-1 & Extracellular \\
\hline 162 & P10599 & Thioredoxin & Cytoplasm \\
\hline 163 & Q16881 & Thioredoxin reductase 1 & Cytoplasm \\
\hline 164 & P07996 & Thrombospondin-1 & Extracellular \\
\hline 165 & P35442 & Thrombospondin-2 & Extracellular \\
\hline 166 & Q6FGX5 & TIMP1 protein & Extracellular \\
\hline 167 & Q15582 & Transforming growth factor-beta-induced protein ig-h3 & Extracellular \\
\hline 168 & 014773 & Tripeptidyl-peptidase 1 & Cytoplasm \\
\hline 169 & Q6EMK4 & Vasorin & Membrane \\
\hline 170 & P13611 & Versican core protein & Extracellular \\
\hline 171 & P08670 & Vimentin & Cytoplasm \\
\hline 172 & P04004 & Vitronectin & Extracellular \\
\hline 173 & 076076 & WNT1-inducible-signaling pathway protein 2 & Extracellular \\
\hline
\end{tabular}

${ }^{\mathrm{a}}$ The subcellular location was determined for each protein based on the Ingenuity Pathway Analysis software (Ingenuity Systems).

digested with PNGase $\mathrm{F}$ in the presence of ${ }^{18} \mathrm{O}$ water to convert any $\mathrm{N}$-glycan-modified Asp to an ${ }^{18} \mathrm{O}$-Asp residue. The resulting peptides were analyzed by LC-MS/MS using the previously described method for ITMS and the parent mass list method for FTMS as described in Materials and
Methods. To obtain the parent mass list, the protein sequences of the 190 identified secreted proteins from Table 1 and Additional file 1: Table S1 were extracted from the database. From these sequences, tryptic peptides, with allowance for two internal missed cleavage sites, that 


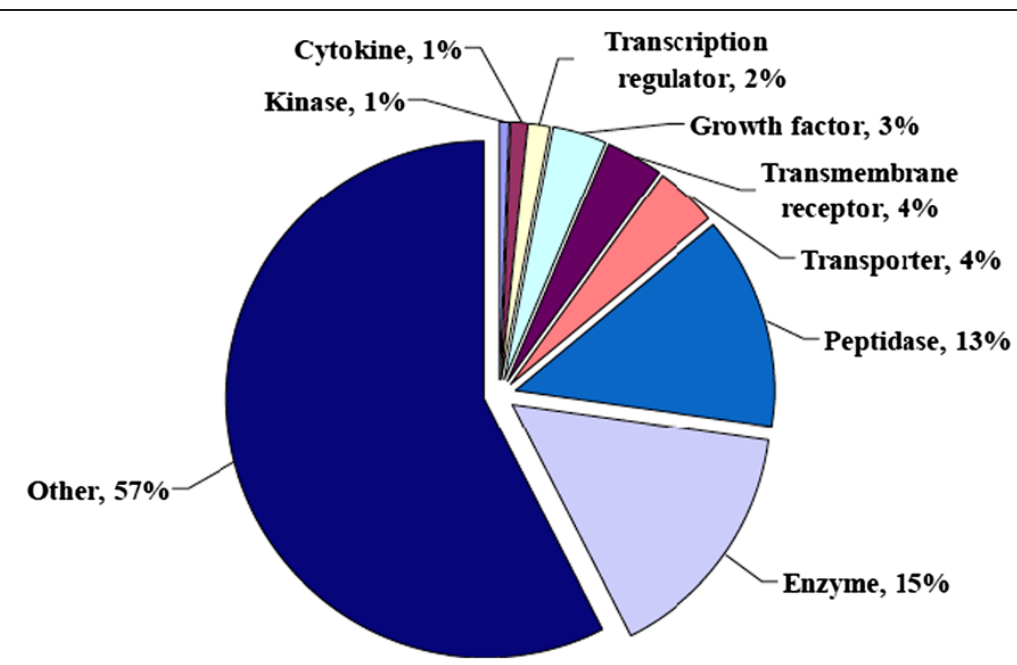

Figure 3 The functional categories of the primary human adipocyte secretome. The biological function analysis was determined for each protein based on the Ingenuity Pathway Analysis software (Ingenuity Systems).

Table 2 Human adipocytokines regulated a minimum of $150 \%$ under both insulin resistant conditaions ${ }^{\text {a }}$

\begin{tabular}{|c|c|c|c|c|c|c|c|c|}
\hline No. & Protein ID & Identified proteins & LGPUG/LG & HGINS/LG & Ave. SC & SD & Ave. peptides & SD \\
\hline 1 & Q96D15 & Reticulocalbin-3 & 9.00 & 8.52 & 11.50 & 2.89 & 3.00 & 1.15 \\
\hline 2 & Q9NRN5 & Olfactomedin-like protein 3 & 5.40 & 7.57 & 13.60 & 6.31 & 3.00 & 0.00 \\
\hline 3 & P09603 & Macrophage colony-stimulating factor 1 & 2.98 & 5.02 & 5.00 & 1.87 & 1.60 & 0.55 \\
\hline 4 & Q59H37 & Laminin alpha 2 subunit isoform b & 1.73 & 4.60 & 11.50 & 6.45 & 4.50 & 1.91 \\
\hline 5 & Q15113 & Procollagen C-endopeptidase enhancer 1 & 1.53 & 4.11 & 14.00 & 3.56 & 3.75 & 0.50 \\
\hline 6 & Q07507 & Dermatopontin & 2.01 & 2.93 & 10.40 & 2.88 & 2.00 & 0.00 \\
\hline 7 & Q02809 & Procollagen-lysine,2-oxoglutarate 5-dioxygenase 1 & 2.70 & 2.80 & 11.17 & 4.83 & 3.83 & 0.98 \\
\hline 8 & P36222 & Chitinase-3-like protein 1 & 1.49 & 2.68 & 26.00 & 8.05 & 6.33 & 0.52 \\
\hline 9 & P05997 & Collagen alpha-2(V) chain & 1.55 & 2.44 & 9.33 & 2.89 & 2.67 & 0.58 \\
\hline 10 & Q9Y240 & C-type lectin domain family 11 member A & 2.07 & 2.44 & 11.00 & 2.00 & 3.00 & 0.00 \\
\hline 11 & Q06828 & Fibromodulin & 1.76 & 2.38 & 15.75 & 2.06 & 2.00 & 1.15 \\
\hline 12 & O00391 & Sulfhydryl oxidase 1 & 2.20 & 2.27 & 8.17 & 3.06 & 2.67 & 0.52 \\
\hline 13 & P15144 & Aminopeptidase N & 2.19 & 2.03 & 22.00 & 13.34 & 4.33 & 1.86 \\
\hline 14 & Q99538 & Legumain & 1.60 & 1.92 & 11.67 & 4.18 & 1.83 & 0.98 \\
\hline 15 & Q6UXB8 & Protease inhibitor 16 & 1.97 & 1.75 & 15.75 & 1.50 & 2.50 & 0.58 \\
\hline 16 & P09486 & SPARC & 1.48 & 1.74 & 263.00 & 169.53 & 10.33 & 1.37 \\
\hline 17 & P07942 & Laminin subunit beta-1 & 1.48 & 1.69 & 63.67 & 13.34 & 16.83 & 1.72 \\
\hline 18 & 075326 & Semaphorin-7A & 1.95 & 1.66 & 21.17 & 8.89 & 3.67 & 1.03 \\
\hline 19 & P10909 & Clusterin & 1.77 & 1.63 & 17.00 & 6.39 & 3.17 & 0.75 \\
\hline 20 & P24821 & Tenascin & 1.61 & 1.54 & 37.33 & 4.76 & 9.83 & 1.72 \\
\hline No. & Protein ID & Identified proteins & LG/LGPUG & LG/HGINS & Ave. SC & SD & Ave. peptides & SD \\
\hline 1 & P61769 & Beta-2-microglobulin & 2.40 & 1.90 & 68.17 & 35.76 & 3.17 & 0.98 \\
\hline 2 & P00739 & Haptoglobin-related protein & 1.87 & 1.66 & 5.67 & 0.58 & 2.00 & 0.00 \\
\hline 3 & Q16270 & Insulin-like growth factor-binding protein 7 & 1.75 & 1.59 & 19.00 & 9.76 & 4.33 & 1.03 \\
\hline 4 & O95965 & Integrin beta-like protein 1 & 1.68 & 1.57 & 9.00 & 1.41 & 3.00 & 0.00 \\
\hline
\end{tabular}

aLPUG: low glucose pluse PUGNAc; HGINS: high glucose pluse insulin as two insulin resistant conditions; Ave. SC: average total spectral count and SD: standard deviation. 


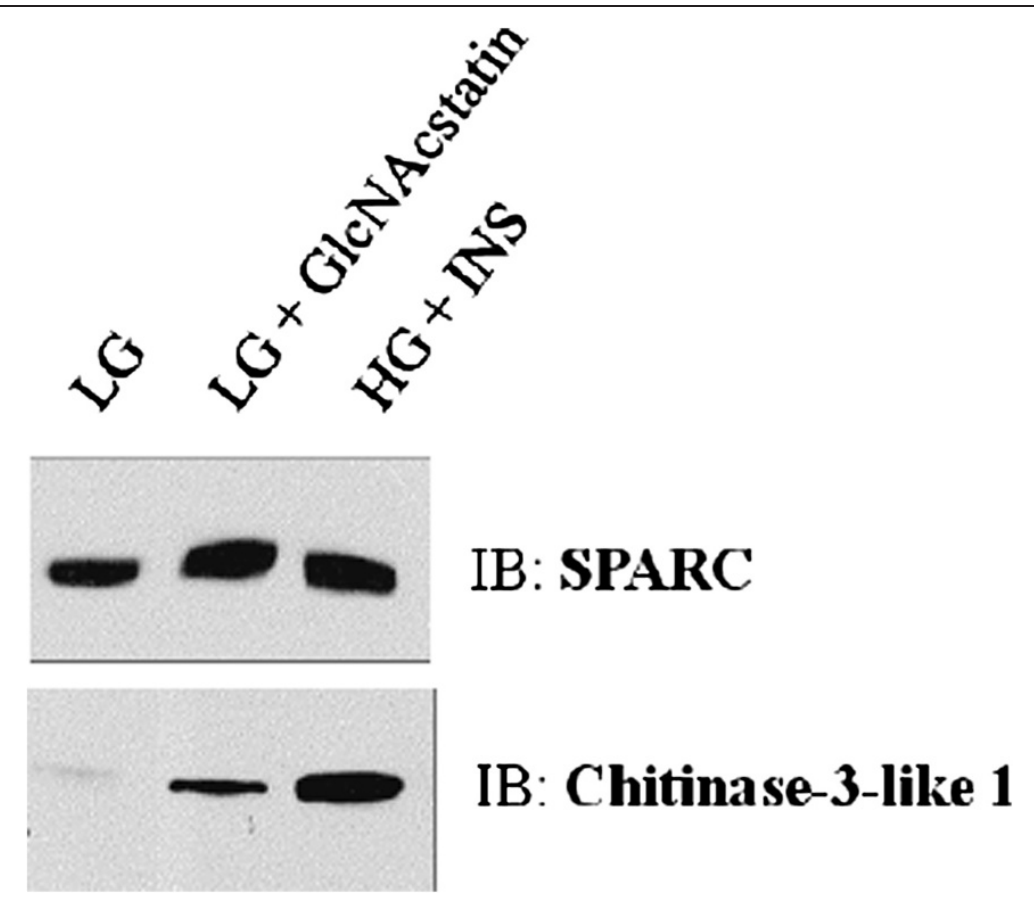

Figure 4 Orthogonal validation of proteomic quantification. Equal amounts of conditioned media from primary human adipocytes was immunoblotted with antibodies against SPARC or Chitinase-3-like protein 1.

contained the consensus sequence, N-X-S/T, were obtained for theoretical mass calculations. Table 3 shows a total of $91 \mathrm{~N}$-linked glycosylation sites that were identified on 52 proteins. These sites covered $10.3 \%$ of the theoretical $882 \mathrm{~N}$-linked glycosylation site sequences generated from the secreted protein list.

\section{Characterization of the human adipocyte glycome}

To better define the glycome of human adipocytes, we performed N-linked and O-linked glycan analysis using mass spectrometry. Glycans were released from whole-cell human adipocyte extracts by PNGase F for N-linked glycans and by $\beta$-elimination for $\mathrm{O}$-linked glycans as shown in Figure $2 \mathrm{C}$. Figure $5 \mathrm{~A}$ shows that the permethylated $\mathrm{N}$ linked glycans were characterized by full FTMS spectrum using a LTQ Orbitrap XL (left panel, top) followed by MS/ MS fragmentation by TIM analysis in the ion trap (left panel, bottom). The fragmentation of a biantennary $\mathrm{N}$ linked glycan is shown as an example. We used the GlycoWorkbench to manually interpret a total of $155 \mathrm{~N}$-linked glycan structures from MS/MS spectra at different charge states as shown in Additional file 1: Table S3. In Figure 5A (right panel), we show that 28 of the predominant Nlinked glycans are assigned to a full FTMS and a MS/MS spectrum.

Figure 5B (left panel) shows a full FTMS spectrum from an O-linked glycan mixture. 10 of the predominant Olinked glycans were assigned from the full FTMS spectra (Figure 5B, bottom panel). A representative fragmentation spectrum is shown for one of the core 2 O-linked glycans (Figure 5B, right panel). A total of 29 O-linked glycans were characterized from MS/MS spectra at singly and doubly charged states as shown in Additional file 1: Table S4.

Relative quantification of the human adipocyte glycome upon the induction of insulin resistance using ${ }^{13} \mathrm{C}$ labeling and prevalence

For the comparative quantification of glycans, we performed isotopic labeling using heavy/light iodomethane $\left({ }^{13} \mathrm{CH}_{3} \mathrm{I}\right.$ and $\left.{ }^{12} \mathrm{CH}_{3} \mathrm{I}\right)[78,79]$. The ${ }^{13} \mathrm{C} /{ }^{12} \mathrm{C}$ ratio from the sum of the peak areas and the prevalence ratio between the different treatment conditions were used for relative quantification. Permethylated glycans were mixed in a 1:1 protein ratio and analyzed in quadruplicate using an LTQ Orbitrap XL. Figure 6A (left panel) shows the isotopic pairs of N-linked glycans on a full FTMS spectrum. Figure 6A (right panel) shows an example of a calculated ${ }^{13} \mathrm{C} /{ }^{12} \mathrm{C}$ ratio from sum of peak area between LG + PUGNAc (LGPUG) and LG conditions. Additional file 1: Table S5 shows a total of $48 \mathrm{~N}$-linked glycans that were relatively quantified between the insulin resistant conditions (LGPUG and HGINS) and insulin responsive condition (LG) by the average ${ }^{13} \mathrm{C} /{ }^{12} \mathrm{C}$ ratio and the average prevalence ratio. This approach simultaneously quantified a broad range of $\mathrm{N}$ glycan structures in a complex mixture; however we did not observe highly significant changes in $\mathrm{N}$-glycan ${ }^{13} \mathrm{C} /{ }^{12} \mathrm{C}$ ratios or prevalence ratios. Figure $6 \mathrm{~B}$ (left panel) shows the isotopic pairs of O-linked glycans on a full FTMS 
Table 3 Identification of $\mathrm{N}$-linked glycosylation sites using PNGase $\mathrm{F}$ with the incorporation of ${ }^{18} \mathrm{O}$ water in human adipocytokines

\begin{tabular}{|c|c|c|c|}
\hline No. & Protein ID & Identifed proteins & $\mathrm{N}$-linked peptides ${ }^{\mathrm{a}}$ \\
\hline 1 & P15144 & Aminopeptidase N & KLN@YTLSQGHR \\
\hline 2 & P21810 & Biglycan & LLQWYLHSNN@ITK \\
\hline 3 & P16870 & Carboxypeptidase E & GN@ETIVNLIHSTR \\
\hline 4 & P07339 & Cathepsin D & GSLSYLN@VTR \\
\hline 5 & P43235 & Cathepsin K & SN@DTLYIPEWEGR \\
\hline 6 & P07711 & Cathepsin L & YSVAN@DTGFVDIPK \\
\hline 7 & P07711 & Cathepsin L & YSVAN@DTGFVDIPKQEK \\
\hline 8 & P10909 & Clusterin & LAN@LTQGEDQYYLR \\
\hline 9 & P02461 & Collagen alpha-1(III) chain & ASQN@ITYHCK \\
\hline 10 & P02461 & Collagen alpha-1(III) chain & DGSPGGKGDRGEN@GSPGAPGAPGHPGPPGPVGPAGK \\
\hline 11 & P20908 & Collagen alpha-1(V) chain & VYCN@FTAGGSTCVFPDKK \\
\hline 12 & P12109 & Collagen alpha-1(VI) chain & ENYAELLEDAFLKN@VTAQICIDKK \\
\hline 13 & P12109 & Collagen alpha-1(VI) chain & GEDGPAGN@GTEGFPGFPGYPGNR \\
\hline 14 & P12109 & Collagen alpha-1(VI) chain & N@FTAADWGQSR \\
\hline 15 & P12109 & Collagen alpha-1(VI) chain & RN@FTAADWGQSR \\
\hline 16 & Q02388 & Collagen alpha-1(VII) chain & TAPEPVGRVSRLQILN@ASSDVLR \\
\hline 17 & Q99715 & Collagen alpha-1(XII) chain & EAGN@ITTDGYEILGK \\
\hline 18 & P08123 & Collagen alpha-2(I) chain & LLANYASQN@ITYHCK \\
\hline 19 & P05997 & Collagen alpha-2(V) chain & EASQN@ITYICK \\
\hline 20 & P12111 & Collagen alpha-3(VI) chain & GNPGEPGLN@GTTGPKGIR \\
\hline 21 & P12111 & Collagen alpha-3(VI) chain & GPPGVN@GTQGFQGCPGQR \\
\hline 22 & P12111 & Collagen alpha-3(VI) chain & GYPGDEGGPGERGPPGVN@GTQGFQGCPGQR \\
\hline 23 & P09871 & Complement $\mathrm{C} 1 \mathrm{~s}$ subcomponent & NCGVN@CSGDVFTALIGEIASPNYPKPYPENSR \\
\hline 24 & O75462 & Cytokine receptor-like factor 1 & VLN@ASTLALALANLN@GSR \\
\hline 25 & O75462 & Cytokine receptor-like factor 1 & WDDVSN@QTSCR \\
\hline 26 & P07585 & Decorin & IADTN@|TSIPQGLPPSLTELHLDGNK \\
\hline 27 & P07585 & Decorin & LGLSFNSISAVDN@GSLANTPHLR \\
\hline 28 & Q9UBP4 & Dickkopf-related protein 3 & GSN@GTICDNQR \\
\hline 29 & Q13822 & Ectonucleotide pyrophosphatase/phosphodiesterase 2 & AEGWEEGPPTVLSDSPWTN@ISGSCK \\
\hline 30 & Q13822 & Ectonucleotide pyrophosphatase/phosphodiesterase 2 & AllAN@LTCK \\
\hline 31 & Q9Y6C2 & EMILIN-1 & LGALN@SSLQLLEDR \\
\hline 32 & P35555 & Fibrillin-1 & TAIFAFN@ISHVSNK \\
\hline 33 & P02751 & Fibronectin & DQCIVDDITYNVN@DTFHKR \\
\hline 34 & P02751 & Fibronectin & DQCIVDDITYNVN@DTFHK \\
\hline 35 & P02751 & Fibronectin & LDAPTNLQFVN@ETDSTVLVR \\
\hline 36 & Q12841 & Follistatin-related protein 1 & GSN@YSEILDK \\
\hline 37 & Q12841 & Follistatin-related protein 1 & GSN@YSEILDKYFK \\
\hline 38 & P09382 & Galectin-1 & FNAHGDANTIVCNSK \\
\hline 39 & Q08380 & Galectin-3-binding protein & ALGFEN@ATQALGR \\
\hline 40 & Q08380 & Galectin-3-binding protein & DAGWCTN@ETR \\
\hline 41 & Q08380 & Galectin-3-binding protein & TVIRPFYLTN@SSGVD \\
\hline 42 & P00738 & Haptoglobin & WLHPN@YSQVDIGLIK \\
\hline 43 & 075629 & Human Protein CREG1 & LN@ITNIMVLDYFGGPK \\
\hline
\end{tabular}


Table 3 Identification of $\mathrm{N}$-linked glycosylation sites using PNGase F with the incorporation of ${ }^{18} \mathrm{O}$ water in human adipocytokines (Continued)

\begin{tabular}{|c|c|c|c|}
\hline 44 & P17936 & Insulin-like growth factor-binding protein 3 & GLCVN@ASAVSR \\
\hline 45 & 014498 & ISLR & SLDLSHNLISDFAWSDLHN@LSALQLLK \\
\hline 46 & Q8NHP8 & LAMA-like protein 2 & SDLNPAN@GSYPFKALR \\
\hline 47 & Q16363 & Laminin subunit alpha-4 & DAVRN@LTEWPQLLDQLR \\
\hline 48 & Q16363 & Laminin subunit alpha-4 & FYFGGSPISAQYAN@FTGCISNAYFTR \\
\hline 49 & Q16363 & Laminin subunit alpha-4 & LITEEAN@R \\
\hline 50 & Q16363 & Laminin subunit alpha-4 & LTLSELDDIIKN@ASGIYAEIDGAK \\
\hline 51 & Q16363 & Laminin subunit alpha-4 & RPASN@VSASIQR \\
\hline 52 & P07942 & Laminin subunit beta-1 & LSDTTSQSN@STAK \\
\hline 53 & P11047 & Laminin subunit gamma-1 & VN@NTLSSQISR \\
\hline 54 & P11047 & Laminin subunit gamma-1 & KYEQAKN@ISQDLEK \\
\hline 55 & P11047 & Laminin subunit gamma-1 & LLNN@LTSIK \\
\hline 56 & P11047 & Laminin subunit gamma-1 & TAN@DTSTEAYNLLLR \\
\hline 57 & P11047 & Laminin subunit gamma-1 & TLAGEN@QTAFEIEELNR \\
\hline 58 & P11047 & Laminin subunit gamma-1 & VNDN@KTAAEEALR \\
\hline 59 & Q14767 & Latent-transforming growth factor beta-binding protein 2 & DGTQQAVPLEHPSSPWGLN@LTEK \\
\hline 60 & P51884 & Lumican & AFEN@VTDLQWLILDHNLLENSK \\
\hline 61 & P51884 & Lumican & LGSFEGLVN@LTFIHLQHNR \\
\hline 62 & P51884 & Lumican & LHINHNN@LTESVGPLPK \\
\hline 63 & P13473 & Lysosome-associated membrane glycoprotein 2 & IAVQFGPGFSWIAN@FTK \\
\hline 64 & P01033 & Metalloproteinase inhibitor 1 & AKFVGTPEVN@QTTLYQR \\
\hline 65 & P01033 & Metalloproteinase inhibitor 1 & FVGTPEVN@QTTLYQR \\
\hline 66 & P01033 & Metalloproteinase inhibitor 1 & SHN@RSEEFLIAGK \\
\hline 67 & Q9NRN5 & Olfactomedin-like protein 3 & IYVLDGTQN@DTAFVFPR \\
\hline 68 & P26022 & Pentraxin-related protein PTX3 & ATDVLN@K \\
\hline 69 & Q15063 & Periostin & EVN@DTLLVNELK \\
\hline 70 & Q15063 & Periostin & IFLKEVN@DTLLVNELK \\
\hline 71 & P98160 & Perlecan & SLTQGSLIVGDLAPVN@GTSQGK \\
\hline 72 & P55058 & Phospholipid transfer protein & VSN@VSCQASVSR \\
\hline 73 & P36955 & Pigment epithelium-derived factor & VTQN@LTLIEESLTSEFIHDIDR \\
\hline 74 & P36955 & Pigment epithelium-derived factor & VTQN@LTLIEESLTSEFIHDIDRELK \\
\hline 75 & P05155 & Plasma protease C1 inhibitor & VGQLQLSHN@LSLVILVPQNLK \\
\hline 76 & P05155 & Plasma protease $\mathrm{C} 1$ inhibitor & VLSN@NSDANLELINTWVAK \\
\hline 77 & P07602 & Proactivator polypeptide [Contains: Saposin-A] & TN@STFVQALVEHVK \\
\hline 78 & P07602 & Proactivator polypeptide [Contains: Saposin-A] & LIDNN@KTEK \\
\hline 79 & P07602 & Proactivator polypeptide [Contains: Saposin-A] & LIDNN@KTEKEILDAFDK \\
\hline 80 & P07602 & Proactivator polypeptide [Contains: Saposin-A] & NLEKN@STK \\
\hline 81 & P07602 & Proactivator polypeptide [Contains: Saposin-A] & NLEKN@STKQEILAALEK \\
\hline 82 & P07602 & Proactivator polypeptide [Contains: Saposin-A] & TN@STFVQALVEHVKEECDR \\
\hline 83 & P09486 & SPARC & VCSNDN@K \\
\hline 84 & P09486 & SPARC & VCSNDN@KTFDSSCHFFATK \\
\hline 85 & P24821 & Tenascin & N@TTSYVLR \\
\hline 86 & P24821 & Tenascin & LN@YSLPTGQWVGVQLPR \\
\hline 87 & P07996 & Thrombospondin-1 & WN@STTGPGEHLR \\
\hline
\end{tabular}




\section{Table 3 Identification of $\mathrm{N}$-linked glycosylation sites using PNGase $\mathrm{F}$ with the incorporation of ${ }^{18} \mathrm{O}$ water in human adipocytokines (Continued)}

\begin{tabular}{|c|c|c|c|}
\hline 88 & P35442 & Thrombospondin-2 & WN@STTGTGEHLR \\
\hline 89 & Q6FGX5 & TIMP1 protein & FVGTPEVN@QTTLYQR \\
\hline 90 & Q6FGX5 & TIMP1 protein & SHN@RSEEFLIAGK \\
\hline 91 & Q6EMK4 & Vasorin & LHEITN@ETFR \\
\hline
\end{tabular}

${ }^{\mathrm{a}} \mathrm{An} @$ indicates the site of $\mathrm{N}$-linked glycosylation.

spectrum. Figure 6B (right panel) shows an example of the calculated ${ }^{13} \mathrm{C} /{ }^{12} \mathrm{C}$ ratio from the sum of peak areas between LGPUG and LG conditions. Additional file 1: Table S6 shows a total of 12 O-linked glycans that were relatively quantified between insulin resistant and insulin sensitive conditions. We did not observe highly significant changes in O-glycan ${ }^{13} \mathrm{C} /{ }^{12} \mathrm{C}$ ratios or prevalence ratios.

\section{Discussion}

Several groups have reported the rodent adipocyte secretome during insulin resistance, but there have been fewer such studies performed with human adipocytes [25,80-82]. It is advantageous to investigate the secretome of human adipose tissue because there are bound to be differences between the rodent and human secretome [8]. The differences in the secretome of human adipose tissue have been investigated during adipogenesis and between different fat pad depots [83-86]. Other studies have characterized the secretome without quantification $[87,88]$. Another approach has been to study a limited list of known adipocytokines during insulin sensitivity and insulin resistance $[89,90]$. Therefore, our study fills an important gap in the literature by taking a discovery approach to characterizing and quantifying the human adipocyte secretome in both insulin sensitive and two different insulin resistance conditions. In addition, we characterize and quantify the glycome of human adipocytes, which has not been described to our knowledge.

We report a total of 193 secreted proteins from human adipocytes (Table 1 and Additional file 1: Table S1). Using Ingenuity Pathways Analysis we determined that many of the secreted proteins were enzymes, peptidases, or other functions (Figure 3). The largest pool of identified proteins from the other category corresponds to extracellular matrix proteins. A common theme among the adipose tissue secretome studies is that extracellular matrix (ECM) proteins, ECM remodelers, inflammatory, and angiogenesis proteins are highly represented $[7,81,87,91]$. The accumulation of fat mass during obesity requires extensive tissue remodeling that is accomplished by ECM remodelers. The remodeling can generate an inflammatory response during obesity and insulin resistance due to limited angiogenesis, localized hypoxia, adipocyte necrosis, increased fibrosis, altered adipocytokine secretion, and M1-stage macrophage and other immune cell infiltration [4,92-96]. Many of the adipocytokines we identified, such as SPARC and Chitinase-3-like protein 1, have been implicated in inflammation [97,98]. In addition, tissue remodeling requires extensive crosstalk between the different cell types that comprise adipose tissue. Several of the adipocytokines we identified, such as Gelsolin, Calreticulin, and Cathepsin D, may be expressed in cell types other than adipocytes $[87,99]$. By using primary adipocytes instead of a cell line, the secretome we identified better represents the physiological status of adipose tissue. In the future, these identified adipocytokines may potentially be used as prognostic/ diagnostic biomarkers for metabolic syndrome, T2DM, and other complications.

We generated insulin resistance in the human adipocytes by both directly and indirectly modulating OGlcNAc levels. The elevation of O-GlcNAc levels has been shown to be sufficient to induce insulin resistance in many systems [19-24]. We have previously demonstrated that the induction of insulin resistance in this way in rodent adipocytes alters the secretion of several adipocytokines [25]. Here, we showed that 20 and 4 adipocytokines were upregulated or downregulated, respectively, upon the transition to insulin resistance by both directly and indirectly modulating O-GlcNAc levels (Table 2). We also identified 28 and 8 adipocytokines that were upregulated or downregulated, respectively, upon the induction of insulin resistance by one of the two methods (Additional file 1: Table S2). In this study, we find that Sulfhydryl oxidase 1 (Quiescin Q6), laminin B1, and Chitinase-3-like protein 1 are upregulated during both insulin resistant conditions, which was also observed in the rodent study. SPARC was upregulated in both insulin resistant conditions in human adipocytes and was found to be upregulated in HG + INS in rodent adipocytes by proteomics. Four other proteins were observed to be regulated by insulin resistance in both rodent and human adipocytes; however, the regulation was slightly different between species. Thioredoxin was downregulated in both insulin resistant conditions in rodent adipocytes and during HG + INS in human adipocytes but was upregulated during LG + PUG in human adipocytes. Gelsolin was upregulated in both insulin resistant conditions in rodent adipocytes and during HG + INS in human adipocytes but was not regulated by LG + PUG. Fibulin 2 was downregulated in both insulin resistant conditions in rodent adipocytes but was not 


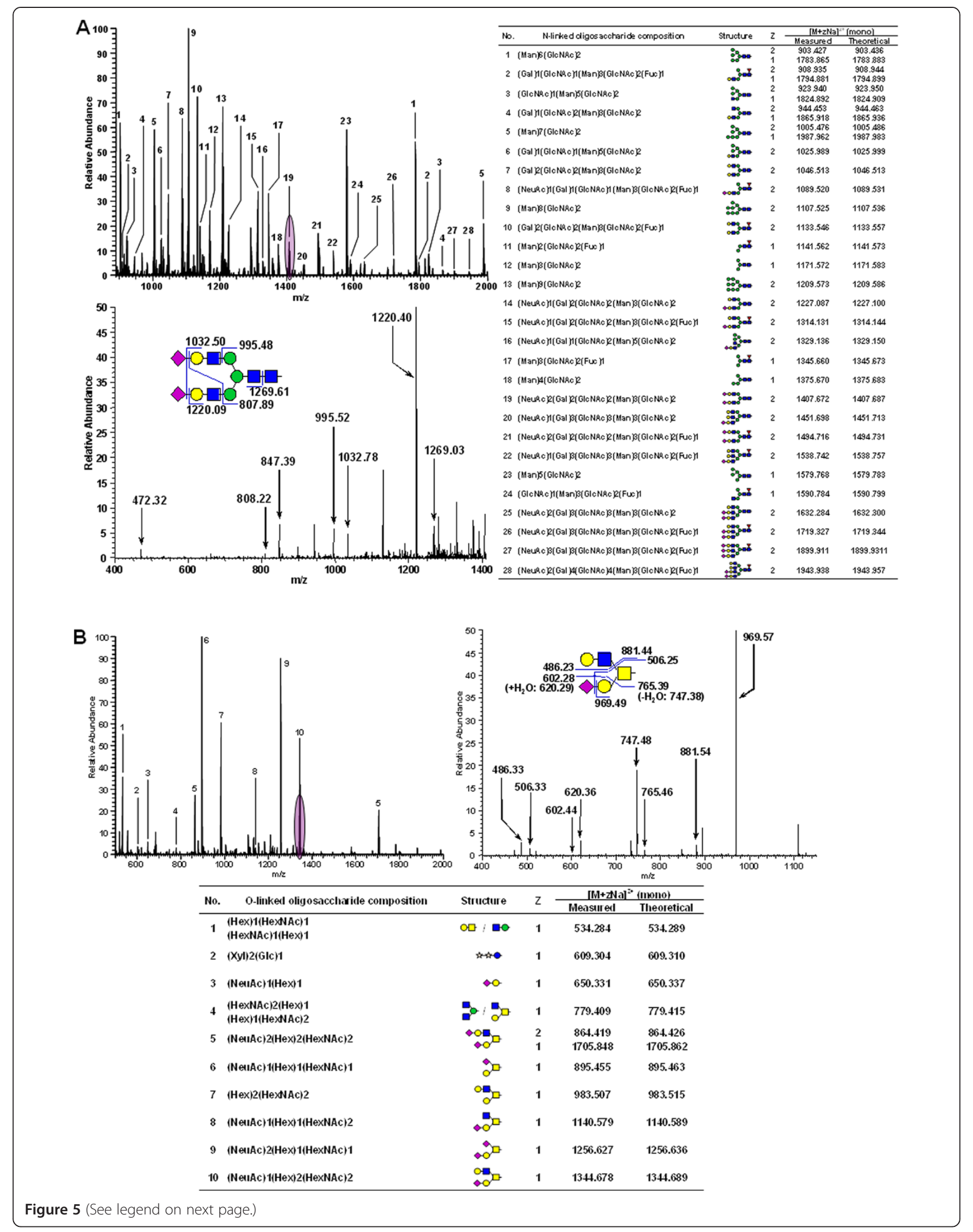


(See figure on previous page.)

Figure $\mathbf{5}$ Characterization of the primary human adipocyte glycome by MS/MS and TIM scan. (A) Upper left panel: a full FTMS spectrum of the N-linked glycan mixture, lower left panel: the characterization of a biantennary complex N-linked glycan structure by MS/MS fragmentation, right panel: a list of predominant N-linked glycans. (B) Upper left panel: a full FTMS spectrum of the O-linked glycan mixture, upper right panel: the characterization of a core 2 O-linked glycan structure by MS/MS fragmentation, lower panel: a list of predominant O-linked glycans. (pink star): Xyl, (red inverted triangle): Fuc, (blue circle): Glc, (green circle): Man, (yellow circle): Gal, (blue square): GlcNAc, (yellow square): GalNAc, and (violet diamond): NeuAc.

regulated or upregulated in LG + PUG and HG + INS, respectively, in human adipocytes. From these examples, it is clear that there are differences in adipocytokine secretion between rodents and humans. Because the proteome sample is extremely complex, we may not have achieved sufficient resolution to quantify some of the proteins that were observed in both rodent and human adipocyte secretomes, such as Angiotensinogen, Cathepsin B, and Spondin 1 [25,100]. Because we assigned significance to a relatively small fold change ( 1.5 fold) for quantification, we verified the regulation of two adipocytokines that changed by 1.5 fold by an independent, orthogonal method. Both SPARC and Chitinase-3-like protein 1 protein levels were altered in a similar manner as measured by both quantitative proteomics and immunoblotting (Figure 4). In addition, the regulation of these proteins by O-GlcNAc was verified using a more OGA-specific Nacetyglucosaminidase inhibitor, GlcNAcstatin.

The inclusion of an insulin resistance condition generated by directly modulating O-GlcNAc levels in our proteomic study helped us to better define the proteins regulated by O-GlcNAc in human adipocytes. The O-GlcNAc modification is found on hundreds in nucleocytosolic proteins and can affect protein function in diverse ways, such as proteinprotein interactions, protein degradation, interplay with phosphorylation, localization, and transcriptional activation [101]. Compiling a list of proteins modulated by O-GlcNAc is the first step in understanding the mechanism of how O-GlcNAc affects adipocytokine expression. We have used the data generated by our previous rodent proteomic study to investigate the transcriptional regulation of adipocytokines by global O-GlcNAc levels (unpublished data). Although several studies have associated elevated O-GlcNAc levels with adipocytokine expression, no specific molecular mechanism has been reported [13-16,21,102,103].

We also characterize the N-linked and O-linked glycome for human adipocytes. Glycosylation and other PTM's provide an additional layer of regulatory complexity to expressed proteins. To understand the full functionality of a protein, one must know the state of the PTM's. Since secretory proteins, such as adipocytokines, are exposed to the glycosylation machinery that reside in the ER and Golgi apparatus as they make their way through the secretory pathway, they often have a high degree of complex glycosylation. The subset of glycans expressed by cells depends on multiple factors, such as developmental stage, tissue type, and the genetic and physiological state of the cell. It is not known whether adipocytes change glycan expression patterns in response to insulin resistance. Since glycosylation can affect diverse processes that are relevant to adipose tissue remodeling in obesity, such as cell-cell interactions, growth factor sequestration, cytokine activation, and cell migration, there is a need to define the adipocyte glycome [34,104,105].

Characterizing the glycome poses many challenges because there is no template for modification, as in DNA, and there is an incredible diversity of glycoforms. Mass spectrometry can provide both structural and abundance information using a small amount of material from a relatively complex mixture [106]. However, it is still difficult to assign specific glycoforms to specific protein residues in a complex mixture. To determine sites of N-glycosylation on the secreted proteins, we used PNGase $\mathrm{F}$ and ${ }^{18} \mathrm{O}$ water to convert the glycan-modified Asn to an ${ }^{18} \mathrm{O}$-Asp residue, thereby leaving a chemical marker of the glycosylation site. We identified 91 sites on 51 proteins of N-linked glycosylation by Orbitrap mass spectrometer using the parent mass list obtained from theoretical consensus sequence in the secretome list (Table 3). For relative glycan quantification, we permethylated using heavy or light iodomethane $\left({ }^{13} \mathrm{CH}_{3} \mathrm{I}\right.$ and $\left.{ }^{12} \mathrm{CH}_{3} \mathrm{I}\right)$ and used prevalence data. The use of isotopic labels allows for mixing of the samples to be compared before analysis, thus providing an internal standard and preventing run to run technical variation $[49,78]$. These techniques allow us to determine the full diversity and changes in major and minor adipocyte glycans during insulin sensitive and resistant conditions. We characterized a total of $155 \mathrm{~N}$-linked glycans and 29 of O-linked glycans (Figure 5, Additional file 1: Table S3, Table S4). The results presented here demonstrate that the human adipocytes are expressing extended hybrid and complex N-linked glycans, in addition to high mannose glycans. Adipose tissues possess the biosynthetic ability to generate diverse O-linked glycans such as core structure, $\mathrm{O}$-glucose glycans, and $\mathrm{O}$-fucose glycans.

Following characterization, we determined the change in glycan prevalence during insulin resistance using isotopic and prevalence ratios. We quantified $48 \mathrm{~N}$-linked glycans and 12 O-linked glycans (Figure 6, Additional file 1: Tables S5-S6). Our results showed that changes of glycan prevalence were not statistically different between 


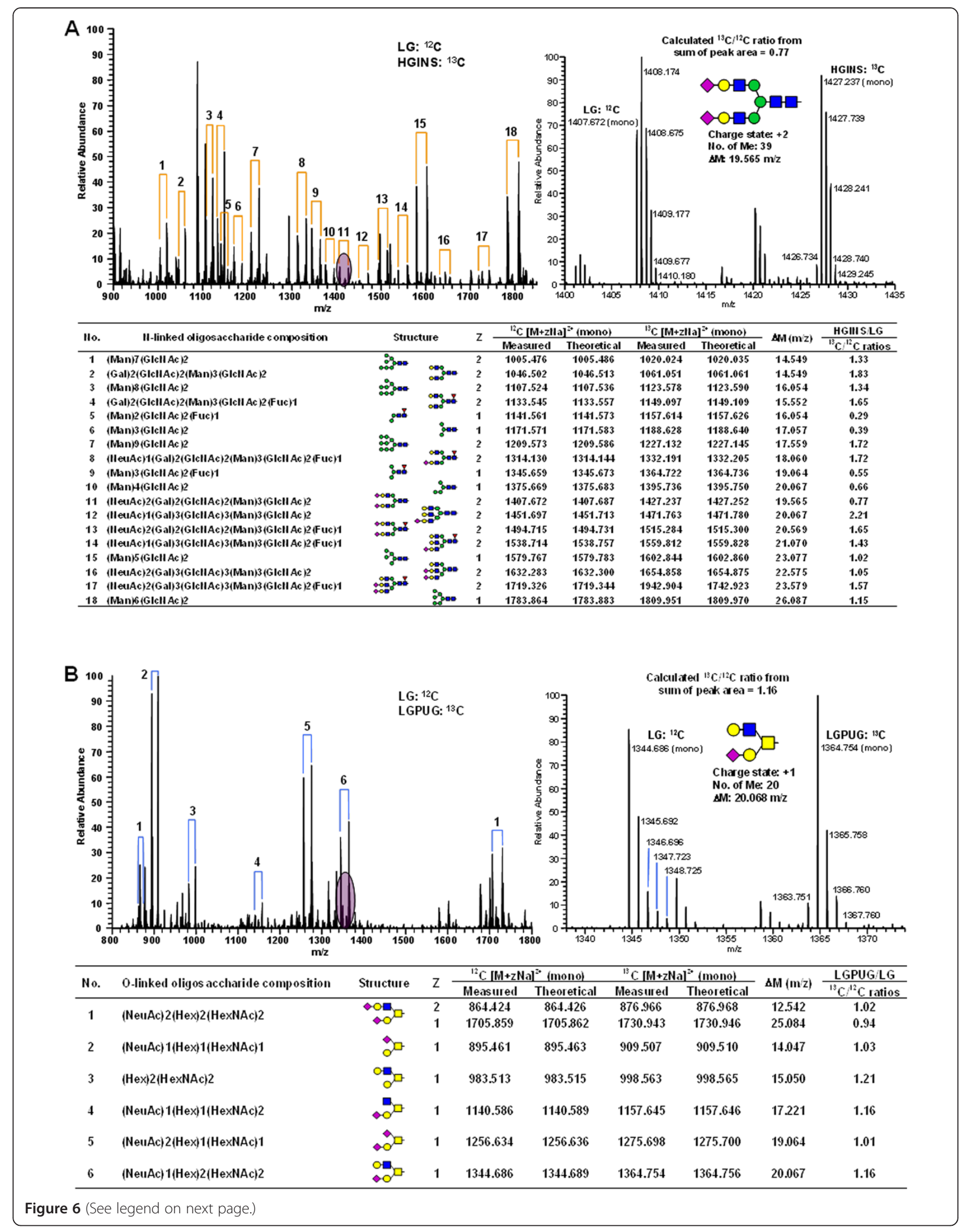


(See figure on previous page.)

Figure 6 Relative quantification of the primary human adipocytes glycome during insulin resistance using ${ }^{13} \mathrm{C} /{ }^{12} \mathrm{C}$ labeling. (A) Upper left panel: a full FTMS spectrum of ${ }^{13} \mathrm{C} /{ }^{12} \mathrm{C}$ labeled $\mathrm{N}$-linked glycans in $\mathrm{HGINS}$ and $\mathrm{LG}$, upper right panel: a FTMS spectrum to calculate ${ }^{13} \mathrm{C} /{ }^{12} \mathrm{C}$ ratios from the sum of isotopic peak areas between the isotopic pairs, lower panel: a list of relative ratios for HGINS and LG for predominant $\mathrm{N}$-linked glycans. (B) Upper left panel: a full FTMS spectrum of ${ }^{13} \mathrm{C} /{ }^{12} \mathrm{C}$ labeled O-linked glycans in LGPUG and LG, upper right panel: a FTMS spectrum to calculate ${ }^{13} \mathrm{C} /{ }^{12} \mathrm{C}$ ratios from the sum of isotopic peak areas between the isotopic pairs, lower panel: a list of relative ratios for $L G P U G$ and LG for predominant O-linked glycans.

the insulin sensitive and insulin resistant conditions. It has been suggested that altering the intracellular UDP-GlcNAc pool, such as during increased glucose flux, changes the degree of $\mathrm{N}$-glycan branching in an ultrasensitive manner [37]. While it is clear that the induction of insulin resistance in adipocytes massively upregulates intracellular glycosylation (Figure 1), we did not observe significant changes in complex glycosylation. This suggests that changes in complex glycosylation are not necessary for the induction of insulin resistance; although we cannot rule out that they play a role in insulin resistance that occurs over a long period of time. Since insulin resistance was generated by treatment for 40 hours, it is possible that the changes in glycan structure had not had time to significantly change.

In conclusion, we have characterized the secretome and glycome of primary human adipocytes during insulin resistance using a proteomic approach. We generated insulin resistance by either directly or indirectly modulating OGlcNAc levels, which provides a list of adipocytokines that are modulated by O-GlcNAc levels. Adipocytokine and glycan levels were quantified between insulin sensitive and insulin resistant conditions and sites of $\mathrm{N}$-glycosylation were identified. This study helps to define the secretome of primary human adipocytes during insulin resistance and helps to characterize and quantify the previously unknown primary adipocyte glycome. Finally, while elevated glucose levels and flux through the hexosamine pathway could theoretically alter both complex glycosylation and O-GlcNAc levels, our findings clearly demonstrate, under the short time frame used here where significant changes were observed in adipocytokine secretion but not in complex glycosylation, that only elevation in O-GlcNAc levels correlate with the observed changes in adipocytokine secretion.

\section{Additional file}

Additional file 1: Table S1. The list of secreted proteins identified by single peptide detection from primary human adipocytes. Table S2. Human adipocytokines regulated a minimum of $150 \%$ under one of the insulin resistant conditions. Table S3. Characterization of total N-linked glycans from primary human adipocytes by MS/MS and TIM scan. Table S4. Characterization of total O-linked glycans from primary human adipocytes by MS/MS and TIM scan. Table S5. Relative quantification of $\mathrm{N}$-linked glycans from primary human adipocytes between insulin resistant conditions and insulin responsive condition by ${ }^{13} \mathrm{C} /{ }^{12} \mathrm{C}$ ratio and prevalence ratio. Table S6. Relative quantification of O-linked glycans from human adipocytes between insulin resistant conditions and insulin responsive condition by ${ }^{13} \mathrm{C} /{ }^{12} \mathrm{C}$ ratio and prevalence ratio.

\section{Competing interests}

The authors declare that they have no competing interests.

\section{Authors' contributions}

$\mathrm{JML}$ participated in the design and execution of experiments and in the writing of the manuscript. EEW-H participated in the execution of experiments as in the writing of the manuscript. CFT and DH participated in the execution of experiments and editing of the manuscript. LW participated in the design of experiments and the writing and final editing of the manuscript. All authors read and approved the final manuscript.

\section{Acknowledgements}

We thank all members of the Wells' laboratory, Ruth Harris, Ron Orlando, and James A. Atwood for helpful discussions. We thank Dr. Daan van Aalten for supplying us with GlcNAcstatin. This work was supported in part by an American Heart Association National Scientific Development Grant (L.W.) and a grant from NIH/NIGMS P41RR018502 (L.W. senior investigator). This research was supported in part by Changwon National University in 2010 and 2013 and by the Basic Science Research Program through the National Research Foundation of Korea (NRF) funded by the Ministry of Education, Science and Technology (grant number: 2011-0013961).

\section{Author details}

${ }^{1}$ Complex Carbohydrate Research Center, The University of Georgia, 315 Riverbend Road, 30602-4712 Athens, Georgia. ${ }^{2}$ Department of Chemistry, The University of Georgia, 30602 Athens, Georgia. ${ }^{3}$ Department of Biochemistry and Molecular Biology, The University of Georgia, 30602 Athens, Georgia. ${ }^{4}$ Department of Foods and Nutrition, The University of Georgia, 30602 Athens, Georgia. ${ }^{5}$ Department of Chemistry, Changwon National University, Changwon, Gyeongnam 641-773, South Korea.

Received: 28 October 2013 Accepted: 4 February 2014

Published: 12 May 2014

\section{References}

1. Prevention., C. f. D. C. a: National diabetes fact sheet: national estimates and general information on diabetes and prediabetes in the United States. Atlanta, GA: US: Department of Health and Human Services, Centers for Disease Control and Prevention; 2011.

2. Brownlee M: The pathobiology of diabetic complications: a unifying mechanism. Diabetes 2005, 54:1615-1625.

3. O'Rahilly S: Human genetics illuminates the paths to metabolic disease. Nature 2009, 462:307-314.

4. Guilherme A, Virbasius JV, Puri V, Czech MP: Adipocyte dysfunctions linking obesity to insulin resistance and type 2 diabetes. Nat Rev Mol Cell Biol 2008, 9:367-377.

5. Harwood HJ Jr: The adipocyte as an endocrine organ in the regulation of metabolic homeostasis. Neuropharmacology 2011.

6. Ouchi N, Parker JL, Lugus JJ, Walsh K: Adipokines in inflammation and metabolic disease. Nat Rev Immunol 2011, 11:85-97.

7. Chen X, Hess S: Adipose proteome analysis: focus on mediators of insulin resistance. Expert Rev Proteomics 2008, 5:827-839.

8. Arner P: Resistin: yet another adipokine tells us that men are not mice. Diabetologia 2005, 48:2203-2205. 
9. Cianflone $K, X i a Z$, Chen LY: Critical review of acylation-stimulating protein physiology in humans and rodents. Biochim Biophys Acta 2003, 1609:127-143.

10. Poulos SP, Dodson MV, Hausman GJ: Cell line models for differentiation: preadipocytes and adipocytes. Exp Biol Med (Maywood) 2010, 235:1185-1193.

11. Marshall S, Bacote V, Traxinger RR: Discovery of a metabolic pathway mediating glucose-induced desensitization of the glucose transport system. Role of hexosamine biosynthesis in the induction of insulin resistance. J Biol Chem 1991, 266:4706-4712.

12. Teo CF, Wollaston-Hayden EE, Wells L: Hexosamine flux, the O-GICNAC modification, and the development of insulin resistance in adipocytes. Mol Cell Endocrinol 2010, 318:44-53.

13. Wang J, Liu R, Hawkins M, Barzilai N, Rossetti L: A nutrient-sensing pathway regulates leptin gene expression in muscle and fat. Nature 1998, 393:684-688.

14. Hazel M, Cooksey RC, Jones D, Parker G, Neidigh JL, Witherbee B, Gulve EA, McClain DA: Activation of the hexosamine signaling pathway in adipose tissue results in decreased serum adiponectin and skeletal muscle insulin resistance. Endocrinology 2004, 145:2118-2128.

15. McClain DA, Alexander T, Cooksey RC, Considine RV: Hexosamines stimulate leptin production in transgenic mice. Endocrinology 2000, 141:1999-2002.

16. Considine RV, Cooksey RC, Williams LB, Fawcett RL, Zhang P, Ambrosius WT, Whitfield RM, Jones R, Inman M, Huse J, McClain DA: Hexosamines regulate leptin production in human subcutaneous adipocytes. J Clin Endocrinol Metab 2000, 85:3551-3556.

17. McClain DA: Hexosamines as mediators of nutrient sensing and regulation in diabetes. J Diabetes Complications 2002, 16:72-80.

18. Wells $\mathrm{L}$, Vosseller $\mathrm{K}$, Hart GW: A role for $\mathrm{N}$-acetylglucosamine as a nutrient sensor and mediator of insulin resistance. Cell Mol Life Sci 2003, 60:222-228.

19. Vosseller K, Wells L, Lane MD, Hart GW: Elevated nucleocytoplasmic glycosylation by O-GICNAc results in insulin resistance associated with defects in Akt activation in 3T3-L1 adipocytes. Proc Natl Acad Sci U S A 2002, 99:5313-5318.

20. Parker GJ, Lund KC, Taylor RP, McClain DA: Insulin resistance of glycogen synthase mediated by o-linked N-acetylglucosamine. J Biol Chem 2003, 278:10022-10027.

21. McClain DA, Lubas WA, Cooksey RC, Hazel M, Parker GJ, Love DC, Hanover JA: Altered glycan-dependent signaling induces insulin resistance and hyperleptinemia. Proc Natl Acad Sci U S A 2002, 99:10695-10699.

22. Arias EB, Kim J, Cartee GD: Prolonged incubation in PUGNAc results in increased protein O-Linked glycosylation and insulin resistance in rat skeletal muscle. Diabetes 2004, 53:921-930.

23. Yang X, Ongusaha PP, Miles PD, Havstad JC, Zhang F, So WV, Kudlow JE, Michell RH, Olefsky JM, Field SJ, Evans RM: Phosphoinositide signalling links O-GIcNAc transferase to insulin resistance. Nature 2008, 451:964-969.

24. Dentin R, Hedrick S, Xie J, Yates J 3rd, Montminy M: Hepatic glucose sensing via the CREB coactivator CRTC2. Science 2008, 319:1402-1405.

25. Lim JM, Sherling D, Teo CF, Hausman DB, Lin D, Wells L: Defining the regulated secreted proteome of rodent adipocytes upon the induction of insulin resistance. J Proteome Res 2008, 7:1251-1263.

26. Chui D, Sellakumar G, Green R, Sutton-Smith M, McQuistan T, Marek K, Morris H, Dell A, Marth J: Genetic remodeling of protein glycosylation in vivo induces autoimmune disease. Proc Natl Acad Sci U S A 2001, 98:1142-1147.

27. Delves PJ: The role of glycosylation in autoimmune disease. Autoimmunity 1998, 27:239-253.

28. Dennis JW, Granovsky M, Warren CE: Glycoprotein glycosylation and cancer progression. Biochim Biophys Acta 1999, 1473:21-34.

29. Gleeson PA: Glycoconjugates in autoimmunity. Biochim Biophys Acta 1994, 1197:237-255

30. Isaji T, Gu J, Nishiuchi R, Zhao Y, Takahashi M, Miyoshi E, Honke K, Sekiguchi K, Taniguchi N: Introduction of bisecting GlcNAc into integrin alpha5beta1 reduces ligand binding and down-regulates cell adhesion and cell migration. J Biol Chem 2004, 279:19747-19754.

31. Krueger KE, Srivastava S: Posttranslational protein modifications: current implications for cancer detection, prevention, and therapeutics. Mol Cell Proteomics 2006, 5:1799-1810.

32. Schachter $\mathrm{H}$ : Congenital disorders involving defective $\mathrm{N}$-glycosylation of proteins. Cell Mol Life Sci 2001, 58:1085-1104.
33. Stanley P: Biological consequences of overexpressing or eliminating $\mathrm{N}$-acetylglucosaminyltransferase-TIII in the mouse. Biochim Biophys Acta 2002, 1573:363-368.

34. Varki A: Biological roles of oligosaccharides: all of the theories are correct. Glycobiology 1993, 3:97-130.

35. Aoki K, Perlman M, Lim JM, Cantu R, Wells L, Tiemeyer M: Dynamic developmental elaboration of $\mathrm{N}$-linked glycan complexity in the Drosophila melanogaster embryo. J Biol Chem 2007, 282:9127-9142.

36. Kudo T, Nakagawa H, Takahashi M, Hamaguchi J, Kamiyama N, Yokoo H, Nakanishi K, Nakagawa T, Kamiyama T, Deguchi K, Nishimura S, Todo S: $\mathrm{N}$-glycan alterations are associated with drug resistance in human hepatocellular carcinoma. Mol Cancer 2007, 6:32.

37. Dennis JW, Nabi IR, Demetriou M: Metabolism, cell surface organization, and disease. Cell 2009, 139:1229-1241.

38. Boehmelt G, Wakeham A, Elia A, Sasaki T, Plyte S, Potter J, Yang Y, Tsang E, Ruland J, Iscove NN, Dennis JW, Mak TW: Decreased UDP-GIcNAc levels abrogate proliferation control in EMeg32-deficient cells. EMBO J 2000, 19:5092-5104

39. Koles K, Lim JM, Aoki K, Porterfield M, Tiemeyer M, Wells L, Panin V: Identification of $\mathrm{N}$-glycosylated proteins from the central nervous system of Drosophila melanogaster. Glycobiology 2007, 17:1388-1403.

40. Lim JM, Aoki K, Angel P, Garrison D, King D, Tiemeyer M, Bergmann C, Wells L: Mapping glycans onto specific N-linked glycosylation sites of Pyrus communis PGIP redefines the interface for EPG-PGIP interactions. J Proteome Res 2009, 8:673-680.

41. Dell A, Reason AJ, Khoo KH, Panico M, McDowell RA, Morris HR: Mass spectrometry of carbohydrate-containing biopolymers. Methods Enzymol 1994, 230:108-132.

42. Morelle W, Faid V, Michalski JC: Structural analysis of permethylated oligosaccharides using electrospray ionization quadrupole time-of-flight tandem mass spectrometry and deutero-reduction. Rapid Commun Mass Spectrom 2004, 18:2451-2464.

43. Prien JM, Huysentruyt LC, Ashline DJ, Lapadula AJ, Seyfried TN, Reinhold VN: Differentiating N-linked glycan structural isomers in metastatic and nonmetastatic tumor cells using sequential mass spectrometry. Glycobiology 2008, 18:353-366.

44. Reinhold VN, Sheeley DM: Detailed characterization of carbohydrate linkage and sequence in an ion trap mass spectrometer: glycosphingolipids. Anal Biochem 1998, 259:28-33.

45. Sheeley DM, Reinhold VN: Structural characterization of carbohydrate sequence, linkage, and branching in a quadrupole lon trap mass spectrometer: neutral oligosaccharides and N-linked glycans. Anal Chem 1998, 70:3053-3059.

46. Viseux N, de Hoffmann E, Domon B: Structural analysis of permethylated oligosaccharides by electrospray tandem mass spectrometry. Anal Chem 1997, 69:3193-3198.

47. Wuhrer M, Deelder AM, Hokke CH: Protein glycosylation analysis by liquid chromatography-mass spectrometry. J Chromatogr B Analyt Technol Biomed Life Sci 2005, 825:124-133.

48. Abbott KL, Aoki K, Lim JM, Porterfield M, Johnson R, O'Regan RM, Wells L, Tiemeyer M, Pierce M: Targeted glycoproteomic identification of biomarkers for human breast carcinoma. J Proteome Res 2008, 7:1470-1480.

49. Aoki K, Porterfield M, Lee SS, Dong B, Nguyen K, McGlamry KH, Tiemeyer M: The diversity of O-linked glycans expressed during Drosophila melanogaster development reflects stage- and tissue-specific requirements for cell signaling. J Biol Chem 2008, 283:30385-30400.

50. Macauley MS, Bubb AK, Martinez-Fleites C, Davies GJ, Vocadlo DJ: Elevation of global O-GlcNAc levels in 3T3-L1 adipocytes by selective inhibition of O-GlcNAcase does not induce insulin resistance. J Biol Chem 2008, 283:34687-34695.

51. Ciucanu I, Kerek F: A simple and rapid method for the permethylation of carbohydrates. Carbohydr Res 1984, 131:209-217.

52. Yates JR 3rd, McCormack AL, Eng J: Mining genomes with MS. Anal Chem 1996, 68:534A-540A

53. Peng J, Elias JE, Thoreen CC, Licklider LJ, Gygi SP: Evaluation of multidimensional chromatography coupled with tandem mass spectrometry (LC/LC-MS/MS) for large-scale protein analysis: the yeast proteome. J Proteome Res 2003, 2:43-50.

54. Kristiansen TZ, Bunkenborg J, Gronborg M, Molina H, Thuluvath PJ, Argani P, Goggins MG, Maitra A, Pandey A: A proteomic analysis of human bile. Mol Cell Proteomics 2004, 3:715-728. 
55. Weatherly DB, Atwood JA 3rd, Minning TA, Cavola C, Tarleton RL, Orlando R: A Heuristic method for assigning a false-discovery rate for protein identifications from Mascot database search results. Mol Cell Proteomics 2005, 4:762-772.

56. Shah P, Gutierrez-Sanchez G, Orlando R, Bergmann C: A proteomic study of pectin-degrading enzymes secreted by Botrytis cinerea grown in liquid culture. Proteomics 2009, 9:3126-3135

57. Park SY, Ryu J, Lee W: O-GIcNAc modification on IRS-1 and Akt2 by PUGNAC inhibits their phosphorylation and induces insulin resistance in rat primary adipocytes. Exp Mol Med 2005, 37:220-229.

58. Dorfmueller HC, Borodkin VS, Schimpl M, Shepherd SM, Shpiro NA van Aalten DM: GlcNAcstatin: a picomolar, selective O-GlcNAcase inhibitor that modulates intracellular O-glcNAcylation levels. J Am Chem Soc 2006, 128:16484-16485.

59. Gygi SP, Rist B, Gerber SA, Turecek F, Gelb MH, Aebersold R: Quantitative analysis of complex protein mixtures using isotope-coded affinity tags. Nat Biotechnol 1999, 17:994-999.

60. Haqqani AS, Hutchison JS, Ward R, Stanimirovic DB: Biomarkers and diagnosis; protein biomarkers in serum of pediatric patients with severe traumatic brain injury identified by ICAT-LC-MS/MS. J Neurotrauma 2007, 24:54-74.

61. Haqqani AS, Nesic M, Preston E, Baumann E, Kelly J, Stanimirovic D: Characterization of vascular protein expression patterns in cerebral ischemia/reperfusion using laser capture microdissection and ICAT-nanoLC-MS/MS. FASEB J 2005, 19:1809-1821.

62. Ong SE, Blagoev B, Kratchmarova I, Kristensen DB, Steen H, Pandey A, Mann M: Stable isotope labeling by amino acids in cell culture, SILAC, as a simple and accurate approach to expression proteomics. Mol Cell Proteomics 2002, 1:376-386.

63. Ong SE, Kratchmarova I, Mann M: Properties of 13C-substituted arginine in stable isotope labeling by amino acids in cell culture (SILAC). J Proteome Res 2003, 2:173-181.

64. Ong SE, Mann M: Mass spectrometry-based proteomics turns quantitative. Nat Chem Biol 2005, 1:252-262.

65. Schnolzer M, Jedrzejewski P, Lehmann WD: Protease-catalyzed incorporation of 180 into peptide fragments and its application for protein sequencing by electrospray and matrix-assisted laser desorption/ ionization mass spectrometry. Electrophoresis 1996, 17:945-953.

66. Shevchenko A, Wilm M, Mann M: Peptide sequencing by mass spectrometry for homology searches and cloning of genes. J Protein Chem 1997, 16:481-490.

67. Uttenweiler-Joseph S, Neubauer G, Christoforidis S, Zerial M, Wilm M: Automated de novo sequencing of proteins using the differential scanning technique. Proteomics 2001, 1:668-682.

68. Andreev VP, Li L, Cao L, Gu Y, Rejtar T, Wu SL, Karger BL: A new algorithm using cross-assignment for label-free quantitation with LC-LTQ-FT MS J Proteome Res 2007, 6:2186-2194.

69. Bondarenko PV, Chelius D, Shaler TA: Identification and relative quantitation of protein mixtures by enzymatic digestion followed by capillary reversed-phase liquid chromatography-tandem mass spectrometry. Anal Chem 2002, 74:4741-4749.

70. Chelius D, Bondarenko PV: Quantitative profiling of proteins in complex mixtures using liquid chromatography and mass spectrometry. J Proteome Res 2002, 1:317-323.

71. Higgs RE, Knierman MD, Gelfanova V, Butler JP, Hale JE: Comprehensive label-free method for the relative quantification of proteins from biological samples. J Proteome Res 2005, 4:1442-1450.

72. Liu H, Sadygov RG, Yates JR 3rd: A model for random sampling and estimation of relative protein abundance in shotgun proteomics. Anal Chem 2004, 76:4193-4201.

73. Mallick P, Schirle M, Chen SS, Flory MR, Lee H, Martin D, Ranish J, Raught B, Schmitt R, Werner T, Kuster B, Aebersold R: Computational prediction of proteotypic peptides for quantitative proteomics. Nat Biotechnol 2007, 25:125-131.

74. Nesvizhskii Al, Keller A, Kolker E, Aebersold R: A statistical model for identifying proteins by tandem mass spectrometry. Anal Chem 2003, 75:4646-4658

75. Old WM, Meyer-Arendt K, Aveline-Wolf L, Pierce KG, Mendoza A, Sevinsky JR Resing KA, Ahn NG: Comparison of label-free methods for quantifying human proteins by shotgun proteomics. Mol Cell Proteomics 2005, 4:1487-1502.
76. Wiener MC, Sachs JR, Deyanova EG, Yates NA: Differential mass spectrometry: a label-free LC-MS method for finding significant differences in complex peptide and protein mixtures. Anal Chem 2004, 76:6085-6096.

77. Dorfmueller HC, Borodkin VS, Schimpl M, van Aalten DM: GlcNAcstatins are nanomolar inhibitors of human O-GIcNAcase inducing cellular hyper-OGlcNAcylation. Biochem J 2009, 420:221-227.

78. Alvarez-Manilla G, Warren NL, Abney T, Atwood J 3rd, Azadi P, York WS, Pierce $\mathrm{M}$, Orlando R: Tools for glycomics: relative quantitation of glycans by isotopic permethylation using 13CH3I. Glycobiology 2007, 17:677-687.

79. Atwood JA 3rd, Cheng L, Alvarez-Manilla G, Warren NL, York WS, Orlando R: Quantitation by isobaric labeling: applications to glycomics. J Proteome Res 2008, 7:367-374.

80. Chen X, Cushman SW, Pannell LK, Hess S: Quantitative proteomic analysis of the secretory proteins from rat adipose cells using a $2 \mathrm{D}$ liquid chromatography-MS/MS approach. J Proteome Res 2005, 4:570-577.

81. Chen X, Hunt D, Cushman SW, Hess S: Proteomic characterization of thiazolidinedione regulation of obese adipose secretome in Zucker obese rats. Proteomics Clin Appl 2009, 3:1099-1111.

82. Zhou H, Xiao Y, Li R, Hong S, Li S, Wang L, Zeng R, Liao K: Quantitative analysis of secretome from adipocytes regulated by insulin. Acta Biochim Biophys Sin 2009, 41:910-921.

83. Hocking SL, Wu LE, Guilhaus M, Chisholm DJ, James DE: Intrinsic depotspecific differences in the secretome of adipose tissue, preadipocytes, and adipose tissue-derived microvascular endothelial cells. Diabetes 2010, 59:3008-3016.

84. Kim J, Choi YS, Lim S, Yea K, Yoon JH, Jun DJ, Ha SH, Kim JW, Kim JH, Suh PG, Ryu SH, Lee TG: Comparative analysis of the secretory proteome of human adipose stromal vascular fraction cells during adipogenesis. Proteomics 2010, 10:394-405.

85. Zhong J, Krawczyk SA, Chaerkady R, Huang H, Goel R, Bader JS, Wong GW, Corkey BE, Pandey A: Temporal profiling of the secretome during adipogenesis in humans. J Proteome Res 2010, 9:5228-5238.

86. Zvonic S, Lefevre M, Kilroy G, Floyd ZE, DeLany JP, Kheterpal I, Gravois A, Dow R, White A, Wu X, Gimble JM: Secretome of primary cultures of human adipose-derived stem cells: modulation of serpins by adipogenesis. Mol Cell Proteomics 2007, 6:18-28.

87. Alvarez-Llamas G, Szalowska E, de Vries MP, Weening D, Landman K, Hoek A, Wolffenbuttel $\mathrm{BH}$, Roelofsen $\mathrm{H}$, Vonk RJ: Characterization of the human visceral adipose tissue secretome. Mol Cell Proteomics 2007, 6:589-600.

88. Rosenow A, Arrey TN, Bouwman FG, Noben JP, Wabitsch M, Mariman EC, Karas $M$, Renes J: Identification of novel human adipocyte secreted proteins by using SGBS cells. J Proteome Res 2010, 9:5389-5401.

89. Fain JN, Madan AK, Hiler ML, Cheema P, Bahouth SW: Comparison of the release of adipokines by adipose tissue, adipose tissue matrix, and adipocytes from visceral and subcutaneous abdominal adipose tissues of obese humans. Endocrinology 2004, 145:2273-2282.

90. Sell H, Dietze-Schroeder D, Eckardt K, Eckel J: Cytokine secretion by human adipocytes is differentially regulated by adiponectin, AICAR, and troglitazone. Biochem Biophys Res Commun 2006, 343:700-706.

91. Roelofsen H, Dijkstra M, Weening D, de Vries MP, Hoek A, Vonk RJ: Comparison of isotope-labeled amino acid incorporation rates (CILAIR) provides a quantitative method to study tissue secretomes. Mol Cell Proteomics 2009, 8:316-324.

92. Hwang CS, Loftus TM, Mandrup S, Lane MD: Adipocyte differentiation and leptin expression. Annu Rev Cell Dev Biol 1997, 13:231-259.

93. MacDougald OA, Lane MD: Transcriptional regulation of gene expression during adipocyte differentiation. Annu Rev Biochem 1995, 64:345-373.

94. Trujillo ME, Scherer PE: Adipose tissue-derived factors: impact on health and disease. Endocr Rev 2006, 27:762-778.

95. Sun K, Kusminski CM, Scherer PE: Adipose tissue remodeling and obesity. J Clin Invest 2011, 121:2094-2101.

96. Olefsky JM, Glass CK: Macrophages, inflammation, and insulin resistance. Annu Rev Physiol 2010, 72:219-246.

97. Nagaraju GP, Sharma D: Anti-cancer role of SPARC, an inhibitor of adipogenesis. Cancer Treat Rev 2011, 37:559-566.

98. Lee CG, Da Silva CA, Dela Cruz CS, Ahangari F, Ma B, Kang MJ, He CH, Takyar S, Elias JA: Role of chitin and chitinase/chitinase-like proteins in inflammation, tissue remodeling, and injury. Annu Rev Physiol 2011, 73:479-501.

99. Dupont A, Tokarski C, Dekeyzer O, Guihot AL, Amouyel P, Rolando C, Pinet F: Two-dimensional maps and databases of the human macrophage proteome and secretome. Proteomics 2004, 4:1761-1778. 
100. Coombs KM: Quantitative proteomics of complex mixtures. Expert Rev Proteomics 2011, 8:659-677.

101. Brimble S, Wollaston-Hayden EE, Teo CF, Morris AC, Wells L: The Role of the O-GlcNAc Modification in Regulating Eukaryotic Gene Expression. Curr Signal Transduct Ther 2010, 5:12-24.

102. Einstein FH, Fishman S, Bauman J, Thompson RF, Huffman DM, Atzmon G, Barzilai N, Muzumdar RH: Enhanced activation of a "nutrient-sensing" pathway with age contributes to insulin resistance. FASEB J 2008, 22:3450-3457.

103. Zhang P, Klenk ES, Lazzaro MA, Williams LB, Considine RV: Hexosamines regulate leptin production in $3 \mathrm{~T} 3-\mathrm{L} 1$ adipocytes through transcriptional mechanisms. Endocrinology 2002, 143:99-106.

104. Taniguchi N, Korekane H: Branched N-glycans and their implications for cell adhesion, signaling and clinical applications for cancer biomarkers and in therapeutics. BMB Rep 2011, 44:772-781.

105. Hart GW, Copeland RJ: Glycomics hits the big time. Cell 2010, 143:672-676.

106. Zaia J: Mass spectrometry and glycomics. OMICS 2010, 14:401-418.

doi:10.1186/1559-0275-11-20

Cite this article as: Lim et al:: Quantitative secretome and glycome of primary human adipocytes during insulin resistance. Clinical Proteomics 2014 11:20.

\section{Submit your next manuscript to BioMed Central and take full advantage of:}

- Convenient online submission

- Thorough peer review

- No space constraints or color figure charges

- Immediate publication on acceptance

- Inclusion in PubMed, CAS, Scopus and Google Scholar

- Research which is freely available for redistribution 